\title{
GOVERNANÇA CORPORATIVA: UM ESTUDO DE CASO NA COOPCREDENSINO
}

\section{Edson Gomes da Silva}

Trabalho de Conclusão de Curso

Centro de CIÊnCIAS SOCIAIS - CCS

DEPARTAMENTO DE ADMINISTRAÇÃo

Graduação em Administração de Empresas 
Edson Gomes da Silva

\title{
Governança Corporativa
}

Um estudo de caso na COOPCREDENSINO

\author{
Trabalho de Conclusão de Curso
}

Trabalho de Conclusão de Curso, apresentado ao programa de graduação em Administração da PUC-Rio como requisito parcial para a obtenção do titulo de graduação em Administração.

Orientador: Ciro Torres

Rio de Janeiro

Novembro de 2021. 
"Se uma grande pedra se atravessa no caminho e 20 pessoas querem passar, não o conseguirão se um por um a procuram remover individualmente. Mas, se as 20 pessoas se unem e fazem força ao mesmo tempo, sob a orientação de uma delas, conseguirão solidariamente afastar a pedra e abrir o caminho para todos". Theodor Amstad - fundador da primeira cooperativa de crédito do Brasil e da América Latina 


\section{Agradecimentos}

Agradeço primeiramente a DEUS e aos meus Orixás, por nunca terem me abandonado em nenhum momento de minha vida. Aos meus pais Orlando Gomes da Silva e minha já falecida mãe, Inanir fiz da Silva, que onde quer que esteja, com certeza estará orgulhosa de seu filho, e a minha esposa e amiga de todas as horas, Bruna Barcelos, que me cobrou por esse momento e me apoiou em todos os instantes.

A meu orientador(a), Prof. Ciro Torres, pela sua disponibilidade, por aceitar essa empreitada sem pestanejar, pela confiança e incentivo que foram fundamentais para realizar e prosseguir este estudo. Saliento o apoio incondicional prestado, a forma interessada, extraordinária e pertinente como acompanhou a realização deste trabalho. As suas críticas construtivas, as discussões sempre em torno do trabalho, e reflexões foram fundamentais ao longo de todo o percurso. Eternamente grato por todo o apoio.

Ao professor Augusto Sampaio que, seja pela cobrança da graduação seja pelo incentivo da conclusão da monografia, sempre me apoiou com palavras encorajadoras.

Meu padrinho Peixe, a pessoa mais incrível que conheci e tive o prazer de trabalhar, uma das pessoas mais humanas e de visão social que tive o prazer de conhecer, sem a sua ajuda seria difícil completar a minha graduação.

Agradeço também a todas as pessoas que contribuíram de forma direta ou indireta para a elaboração deste trabalho. 


\section{Resumo}

Gomes da Silva, Edson. Governança Corporativa - Um estudo de caso na Coopcred-Ensino. Rio de Janeiro, 2021. 62p. Trabalho de Conclusão de Curso - Departamento de Administração. Pontifícia Universidade Católica do Rio de Janeiro.

O presente trabalho discorre acerca da Governança Corporativa nas Cooperativas de Crédito no Brasil. Tem como objeto geral a análise da gestão de Cooperativas de Crédito no Brasil buscando como objeto específico a proposta de implantação da boa Governança Corporativa como possibilidade colaborativa de um ideal "máximun", ou um tipo ideal, na boa gestão das cooperativas de crédito no Brasil.

O estudo buscou identificar as principais práticas de governança adotadas por uma cooperativa de credito de ensino de acordo com Manual de Boas Práticas de Governança Cooperativa, verificando através de pesquisas bibliográficas o funcionamento e origem das cooperativas de crédito, o surgimento das boas práticas de governança no Brasil e no mundo, e a sua colaboração para as cooperativas de crédito.

O tema escolhido mostrou, a partir do estudo do Caso da CoopcredEnsino, a necessidade de levar às Cooperativas de Créditos um sistema de gestão de excelência e com políticas alinhadas ao compliance, que vem ganhando a atenção de organizações em todo o mundo, pois além de adequar as atividades da empresa, gera informações seguras a respeito de sua atuação e mantém o negócio funcionando.

\section{Palavras-chave}

Cooperativismo, Gestão, Governança corporativa, cooperativa de crédito 


\section{Abstract}

Gomes da Silva, Edson. Corporate Governance - A case study at CoopcredEnsino. Rio de Janeiro, 2021. 62p. Trabalho de Conclusão de Curso - Departamento de Administração. Pontifícia Universidade Católica do Rio de Janeiro.

This paper discusses Corporate Governance in Credit Cooperatives in Brazil. Its general object is the analysis of the management of Credit Unions in Brazil, seeking as a specific object the proposal to implement good Corporate Governance as a collaborative possibility of a "maximum" ideal, or an ideal type, in the good management of credit unions in the Brazil.

The study sought to identify the main governance practices adopted by an educational credit cooperative in accordance with the Manual of Good Cooperative Governance Practices, verifying through bibliographic research the functioning and origin of credit unions, the emergence of good governance practices in Brazil and in the world, and its collaboration with credit unions.

The chosen theme showed, from the study of the Coopcred PUC case... the need to bring to Credit Cooperatives a management system of excellence and with policies aligned with compliance, which has been gaining the attention of organizations around the world, as in addition to adapting the company's activities, it generates secure information about its operations and keeps the business running.

Key-words

Cooperatives, Management, Corporate Governance, Credit Union 
Lista de abreviaturas e siglas

OCB Organização das Cooperativas Brasileiras

MEI Microempreendedores individuais

OTS Organização do Terceiro Setor

CRESOL Cooperativa de Crédito Rural com Interação Solidária

SESCOOP Serviço Nacional de Aprendizagem do Cooperativismo

SICOOBCOPERMEC

Sicredi Sistema de Crédito Cooperativo

IBCA Instituto Brasileiro de Conselheiros de Administração

IBGC Instituto Brasileiro de Governança Corporativa

BACEN Banco Central

CMN Conselho Monetário Nacional

FGCoop (Fundo Garantidor de Crédito das Cooperativas)

Lista de tabelas, figuras e gráficos

Tabela 1 - Os Sete Princípios do Cooperativismo

Figura 1 - Estrutura Organizacional de uma cooperativa - Organograma

Figura 2 - Estrutura Organizacional da Coopcred- Ensino

Tabela 2 - Diferenças entre Cooperativa de Crédito e as demais Instituições Financeiras;

Quadro 1 - Comparativo de taxas de juros médias por Modalidade de crédito

Tabela 3 - Práticas de Boa Governança 


\section{Sumário}

1 . Introdução 1

1.1. Objetivo Geral 2

1.2. Objetivo Específico 2

1.3. Delimitação do estudo 2

2. Referencial Teórico 3

2.1. Cooperativismo 3

2.1.1. Origem 3

2.1.2. Princípios e Valores cooperativistas 4

2.2. Tipologia das Organizações 5

2.2.1. Organização do Terceiro Setor 7

2.2.1.1. Cooperativa 8

2.2.1.2. Forma Legal da Constituição 8

2.2.1.3. Seguimentos de Atividades Econômicas 9

$\begin{array}{ll}\text { 2.2.2. Gestão/ Administração } & 10\end{array}$

2.2.3. Estrutura Organizacional de Cooperativa 12

2.2.4. Cooperativa de Crédito 15

2.2.4.1. Diferença entre cooperativa de crédito e bancos 16

$\begin{array}{ll}\text { 2.3. Governança Corporativa } & 17\end{array}$

2.3.1. Origem 18

2.3.2. Governança Corporativa no Mundo 19

2.3.3. Governança Corporativa no Brasil 19

2.3.4. Prática de Boa Governança Corporativa 20

2.3.5. Princípios da Governança Corporativa 21

2.3.6. Governança em Cooperativas de Crédito 21

2.3.7. Diretrizes para as boas práticas da Governança Corporativa nas Cooperativas de Crédito 22

2.3.7.1. Estrutura das Diretrizes 22

2.3.7.2. Representatividade e participação 23

2.3.7.3. Direção estratégica 23 
2.3.7.4. Gestão Executiva

2.3.7.5. Fiscalização e Controle 24

2.3.7.6. Associados 24

2.3.7.7. Auditorias 25

2.3.7.8. Relatório de Auditoria 26

2.3.7.9. Conselho Fiscal 27

2.3.7.10. Organização Sistêmica 27

3. Metodologia 29

3.1. Método Dialético 29

3.2. Classificação da pesquisa 29

3.2.1. Quanto aos fins 30

3.2.2. Quanto aos meios 30

4. Apresentação e análise dos resultados 32

4.1. Apresentação da Cooperativa estudada 32

4.2. Análise e Diagnóstico 35

4.2.1. Participação na Cooperativa 35

4.2.2. Assembleias Gerais 36

4.2.3. Apresentação de resultados e eleições 38

4.2.4. Auditoria 39

4.2.5. Conselho Fiscal 40

4.2.6. Conselho de Administração 41

4.2.7. Código de conduta e padrões éticos 42

4.2.8. Ouvidoria 43

4.2.9. Sobras 43

4.3. Outras informações relevantes 44

5. Conclusões e Sugestões 48

Referências Bibliográficas $\quad 51$ 


\section{Introdução}

O cooperativismo de crédito tem grande relevância na economia do país e vem se expandindo e consolidando substancialmente nos últimos anos. A importância do cooperativismo no cenário brasileiro tem firmado sua participação e posição de destaque contribuindo no desenvolvimento social e econômico do país, na construção de uma sociedade mais justa.

Segundo a OCB (Organização das Cooperativas Brasileiras), atualmente 13,2 milhões de cooperados são vinculados às 6.655 instituições que operam no Brasil, gerando cerca de 380 mil empregos diretos. O ramo crédito corresponde aproximadamente à sexta parte do total de empresas e congrega em torno de 9 milhões de pessoas físicas e jurídicas, segundo dados do FGCoop (Fundo Garantidor de Crédito das Cooperativas).

As cooperativas de crédito aparecem como instituições alternativas no fornecimento de crédito, com aspectos diferentes utilizados pelos bancos, pois arcam com os riscos de suas aplicações em prol da comunidade. O elevado nível de competitividade impõe compensações para que as cooperativas cheguem ao estágio imposto pelo mercado, desenvolvendo mecanismos que assegurem a sua sustentabilidade, avançando e aprimorando suas estruturas de gestão e de governança.

As cooperativas de crédito procuram atuar de forma eficaz, considerando a competitividade do sistema bancário, visto que possuem importância social e econômica na sociedade (SILVA, LEITE, et al., 2017). O mercado financeiro mostra-se em constantes transformações, dentre elas ganhos e perdas econômicas. Deste modo, o mercado vem exigindo das empresas maior transparência e confiabilidade nas informações e demonstrações contábeis, bem como uma gestão que reflita credibilidade. De tal modo, percebe-se que as boas práticas de Governança Corporativa se tornaram cada vez mais relevantes para as organizações (SOUZA; BAUER; COLETTI, 2020). 
Diante deste cenário de mudanças, as cooperativas tiveram que se submeter às constantes melhorias na capacitação de dirigentes e colaboradores e na disseminação de boas práticas de gestão, elevando a transparência e controle, gerando mais confiança, atraindo capital, garantindo eficiência e entrega de bons resultados.

\subsection{Objetivo Geral}

O objetivo geral deste estudo é verificar como a implantação da Governança Corporativa tem contribuído para a cooperativa de crédito e sua importância nesse processo.

\subsection{Objetivo Específico}

Visando a alcançar o objetivo final, os seguintes objetivos específicos foram selecionados:

- Realizar pesquisa bibliográfica descritiva de como opera uma cooperativa de crédito;

- Pesquisar referencial bibliográfico sobre Governança Corporativa no Brasil e no mundo;

- Averiguar a importância das boas práticas de Governança Corporativa na Cooperativa de Crédito, para o desenvolvimento efetivo da gestão das cooperativas;

- Apurar a aplicabilidade da Governança Corporativa na cooperativa de crédito em estudo;

- Detectar os proveitos esperados pela aplicação da Governança Corporativa na cooperativa de crédito em estudo.

\subsection{Delimitação do estudo}

O estudo tem como meta abordar o tema da aplicação da Governança Corporativa em uma Cooperativa de Crédito. Partiremos das informações colhidas junto à Coopcred-Ensino - Cooperativa de Economia e Crédito mútuo dos empregados da Pontifícia Universidade Católica do Rio de Janeiro e empregados em estabelecimentos privados de ensino do Município do Rio de Janeiro.

Não serão abordados dados financeiros da cooperativa em estudo. 


\section{Referencial Teórico}

\subsection{Cooperativismo}

O cooperativismo é um sistema econômico e social baseado na cooperação entre pessoas, com base comum criado na Europa no século XIX, espalhado por todo o mundo. Nesse tipo de modelo organizacional os trabalhadores são donos do próprio negócio. O objetivo maior não está relacionado necessariamente ao lucro, e sim, satisfazer as necessidades humanas e resolver os problemas comuns, garantindo aos cooperados melhores oportunidades e um futuro mais justo.

Segundo o Sistema da OCB é um movimento econômico e social, entre pessoas, em que o apoio se baseia na participação dos associados nos negócios com vistas a atingir o bem comum e promover uma reforma social dentro do capitalismo. Por meio da cooperação, busca-se conhecer as necessidades humanas e resolver os problemas comuns. O fim maior é o homem, não o lucro.

\subsubsection{Origem}

A partir de dados históricos pode-se afirmar que o cooperativismo tem suas origens na organização dos trabalhadores na Inglaterra durante a Revolução Industrial, no século 18 na cidade de Manchester.

Conforme destacado por Pinho (1982), o cooperativismo, da forma como se conhece hoje, teve seu início no século XIX. As transformações que marcaram o século passado, o surgimento de novas ideias e filosofias principalmente a Revolução Industrial - formaram o terreno fértil para o aparecimento do cooperativismo (LIMA, 1944; ZEULI; CROPP, 2004). 
Com a finalidade de melhorar a própria situação econômica em 28 de outubro de 1844, em Rochdale, distrito de Lancashine, na Inglaterra, 28 tecelões desempregados, sendo, destes, uma tecelã. se aglutinam e instituem a primeira cooperativa moderna do mundo, (a sociedade dos probos).

Movimento este que estava diretamente ligado às iniciativas dos trabalhadores contra as opressões estatal e empresarial (BEGNIS; AREND; ESTIVALETE, 2014), "pautados em ideias de justiça social e solidariedade" (MORAIS et al.,2011, p. 68).

Foi em Ouro Preto (MG), que nasceu a primeira sociedade brasileira a ter no nome a expressão "cooperativa", a Sociedade Econômica Cooperativa dos Funcionários Públicos de Ouro Preto, fundada em 27 de outubro de 1889, cujo foco era o consumo de produtos agrícolas. No ano de 1902 em Nova Petrópolis/RS, através de uma iniciativa do padre suíço Theodor Amstad, com a intenção de amparar às dificuldades financeiras das famílias da região, nasce a primeira cooperativa de credito no Brasil e na América Latina.

\subsubsection{Princípios e Valores cooperativistas}

As cooperativas baseiam-se em valores de ajuda mútua, responsabilidade, democracia, igualdade, equidade e solidariedade. $\mathrm{Na}$ tradição de seus fundadores, os cooperativistas acreditam nos valores éticos da honestidade, transparência, responsabilidade social e preservação do ambiente para 0 desenvolvimento sustentado.

Para orientar os cooperativistas ao redor do mundo as organizações das cooperativas seguem sete princípios de modo a criar uma identidade única nos mercados em que atuam. Esses princípios foram estabelecidos na formação da primeira cooperativa, pelos 28 tecelões pioneiros de Rochdale no ano de 1844, na Inglaterra.

Para Oliveira (2001), os sete princípios devem ser incorporados pela gestão, ampliando-os em seus significados originais, para que sejam contempladas as questões de planejamento, organização, direção e avaliação 
das cooperativas, confirmando a importância destes princípios no fortalecimento do cooperativismo.

$\mathrm{Na}$ Tabela 1 encontramos os sete princípios do cooperativismo, segundo o Sistema OCB:

Tabela 1 - Os Sete Princípios do Cooperativismo

\begin{tabular}{|l|l|}
\hline \multicolumn{1}{|c|}{ Princípio } & \multicolumn{1}{c|}{ Descrição } \\
\hline $\begin{array}{l}\text { Adesão livre e } \\
\text { voluntária }\end{array}$ & $\begin{array}{l}\text { Qualquer pessoa pode se associar a uma cooperativa, sem qualquer } \\
\text { discriminação, desde que esteja alinhada ao seu objetivo econômico, } \\
\text { e disposta a assumir sua responsabilidade como membro. }\end{array}$ \\
\hline $\begin{array}{l}\text { Gestão } \\
\text { democrática }\end{array}$ & $\begin{array}{l}\text { Todos os membros participam ativamente na formulação de suas } \\
\text { políticas e na tomada de decisões. }\end{array}$ \\
\hline $\begin{array}{l}\text { Participação } \\
\text { memonbrosica dos }\end{array}$ & $\begin{array}{l}\text { Em uma cooperativa, os membros contribuem equitativamente para } \\
\text { o capital da organização }\end{array}$ \\
\hline $\begin{array}{l}\text { Autonomia } \\
\text { independência }\end{array}$ & $\begin{array}{l}\text { As cooperativas são organizações autônomas, de ajuda mútua, } \\
\text { controladas por seus membros. }\end{array}$ \\
\hline $\begin{array}{l}\text { Educação, } \\
\text { formação } \\
\text { informação }\end{array}$ & $\begin{array}{l}\text { Comprometimento em promoção da educação e formação de } \\
\text { membros e colaboradores que possam contribuir para o } \\
\text { desenvolvimento dos negócios e, consequentemente, dos lugares } \\
\text { onde estão presentes. }\end{array}$ \\
\hline $\begin{array}{l}\text { Intercooperação } \\
\text { comunidade }\end{array}$ & $\begin{array}{l}\text { Cooperativismo é trabalhar em conjunto. É assim, atuando juntas, } \\
\text { que as cooperativas dão mais força ao movimento e servem de } \\
\text { forma mais eficaz aos cooperados. }\end{array}$ \\
$\begin{array}{l}\text { Contribuir para o desenvolvimento sustentável das comunidades é } \\
\text { algo natural ao cooperativismo. }\end{array}$ \\
\hline
\end{tabular}

Elaborado pelo próprio autor deste estudo, 2021.

\subsection{Tipologia das Organizações}

As organizações são grupos estruturados de pessoas que se juntam para alcançar objetivos comuns. Surgem como resposta à necessidade dos indivíduos 
de alcançar metas mais ambiciosas, impossíveis de serem atingidas individualmente, em virtude da complexidade e da variedade das tarefas inerentes ao trabalho a se efetuar. Podem ser organizações formais, como no caso de um exército ou de uma empresa, ou informais, como um grupo de amigos que se junta para jogar vôlei na praia. No entanto, independentemente de sua forma e atividade, as organizações compartilham algumas características.

Primeiro setor são as organizações públicas que tem o propósito de desempenhar o papel de Estado, neles estão contidos prefeitura, governo estaduais e suas respectivas secretarias, governo federal e seus ministérios, enfim, todos os equipamentos públicos. Neles são usados recursos públicos para fins públicos, o objetivo desse setor é gerir, executar e criar políticas públicas que possam garantir direitos básicos a todos os cidadãos, como saúde, educação, segurança pública, esporte, lazer, cultura entre outros.

Segundo setor é o setor de geração de lucro, composto por empresas privadas, nesse setor, serão utilizados recursos privados para fins privados, seu objetivo ao longo do tempo é que essas organizações gerem lucro aos seus donos. Importante ressaltar que todas as empresas fazem parte do segundo setor, não somente as de grande porte e multinacionais, pequenas empresas como bares, lojas, padarias, salões de beleza, farmácias entre outras, todas se encontram nesse setor, e tem também os microempreendedores individuais "MEls".

O terceiro setor não tem o dividendo como meta, utilizasse em sua maioria recursos privados para fins públicos. Elas podem receber recursos tanto do primeiro como do segundo setor, o governo pode desperdiçar recursos, as empresas privadas podem disponibilizar recursos e até pessoas físicas também podem ceder capital para as OTS. Sua finalidade é resolver problema na sociedade em geral uma vez que o estado não é capaz de prover todas as necessidades da população, já as privadas podem ajudar na entrega de serviços, mas o principal objetivo delas é o lucro.

Pode-se declarar que a nomenclatura Terceiro Setor se caracteriza por congregar as organizações privadas com finalidades públicas. Diferencia-se, nesse sentido, do primeiro Setor (composto de organizações governamentais) e 
do Segundo Setor (formado por organizações não governamentais com fins lucrativos) (PRANDO; FILHO, 2006, p. 16).

\subsubsection{Organização do Terceiro Setor}

De origem norte americana e bastante utilizada nos Estados Unidos, a expressão Third Sector, são as organizações sem fins lucrativos e apesar de atuarem em diversas áreas da sociedade, não pertencem nem a esfera do Estado (1ำ setor) nem a do Mercado (2ํsor).

As Organizações do Terceiro Setor são a tradução do termo americano de Third Sector e suas atividades são provenientes de trabalhos voluntários sem remuneração (FERNANDES, 1997, p.1).

Pode-se conceituar o Terceiro Setor como um conjunto de organismos, organizações ou instituições civis de qualquer origem que não objetivam retorno financeiro. Podem variar de tamanho, nível de formalização, quantidade de recursos, objetivo institucional e também quanto a forma de atuação no mercado, formadas por organizações religiosas, associações, fundações, sindicatos, cooperativas, federações e confederações com os mais diversos fins.

Segundo a proposta de Salamon e Anheier (1992) para ser definida como uma OTS a estrutura operacional deve ser formal, privada, não distributiva de lucros, autônoma e voluntária. Além desses cinco critérios as OTS devem ter seus próprios procedimentos de governança.

As cooperativas fazem parte do Terceiro Setor devido a diretriz jurídica que ela possui, porém com uma funcionalidade diferente. Ela promove o desenvolvimento socioeconômico no mundo todo aumentando o acesso a serviços e recursos que em outro cenário não seria possível aos seus integrantes. Apesar de não ter fins lucrativos pode acontecer de haver valores remanescentes entre a arrecadação e as despesas, tais valores são direcionados para fins específicos como um fundo de reserva para garantir a liquidez da Cooperativa por exemplo. 


\subsubsection{Cooperativa}

A expressão cooperativa dispõe de diversos conceitos e que se modificam de acordo com a época e a orientação teórica que foram gerados, tornando árduo achar uma ideia única que manifeste sua pluralidade. A Lei nำ 5.764/71, estabelece no seu artigo $4^{\circ}$.: "As cooperativas são sociedades de pessoas, com forma e natureza jurídica próprias, de natureza civil, não sujeitas a falência, constituídas para prestar serviços aos associados, distinguindo-se das demais sociedades..."

Por não ter o lucro como meta a ser alcançada e possuir fins econômicos e sociais, torna as cooperativas uma organização possuidora de duplo caráter, ou seja, uma associação de indivíduos, constituída por no mínimo 20 pessoas físicas, sendo excepcionalmente permitida a admissão de pessoas jurídicas, que se reúnem com o objetivo de gerar soluções com embasamento no associativismo, é também uma organização empresarial, sem fins lucrativos, embora tenha fins econômicos e sociais.

A OCB (Organização das Cooperativas Brasileiras), define cooperativa como: "Uma sociedade de, pelo menos, vinte pessoas físicas, unidas pela cooperação e ajuda mútuas, gerida de forma democrática e participativa, com objetivos econômicos e sociais comuns, cujos aspectos legais e doutrinários são distintos das outras sociedades" (X Congresso Brasileiro de Cooperativismo - Brasília, 1988).

\subsubsection{Forma Legal da Constituição}

As cooperativas no Brasil estão estabelecidas na Constituição Federal, no Novo Código Civil e também por uma lei própria, a 5.764/71, conhecida como Lei do Cooperativismo. Neles estão expostas as leis que dominam o modelo em nosso País e que embasam sua organização.

O processo de mais estabilidade, se deu por via desta edição, as cooperativas passaram a dispor da proteção de um código específico e completo, que estabelece a Política Nacional do Cooperativismo. 


\subsubsection{Seguimentos de Atividades Econômicas}

Segundo o CRESOL No Brasil, as cooperativas eram constituídas por 13 segmentos de atividades econômicas até o ano de 2019. Para garantir a modernização e ficar mais próxima à atualidade a OCB no ano de 2020 resume o cooperativismo a sete ramos.

Abaixo cada um dos sete segmentos do cooperativismo brasileiro:

- Agropecuário: esse segmento abrange as cooperativas de produtores rurais e de pescadores, entre outras. A união das forças ajuda na comercialização e no armazenamento da produção, além de possibilitar assistência técnica para os associados.

- Crédito: o grupo é composto por cooperativas que prestam serviços financeiros, como empréstimo, financiamento e aplicações. Elas têm o objetivo de facilitar a entrada dos participantes no mercado, já que operam com taxas mais baixas e com menos burocracia.

- Transporte: esse setor envolve as pessoas que atuam no transporte de passageiros e aquelas que transportam carga. Para tanto, os cooperados devem ser proprietários dos veículos em circulação. Há modalidades variadas dessas cooperativas - para táxi, ônibus, transporte escolar, frete de mercadorias etc. Cada uma tem suas especificidades.

- Trabalho, Produção de Bens e Serviços: esse segmento do cooperativismo contempla a prestação de serviços especializados, indo do turismo ao beneficiamento de material reciclável. As organizações surgem para elevar a remuneração e as condições de trabalho de uma determinada categoria.

- Saúde: essas associações cooperativas são formadas por médicos, dentistas ou outros profissionais da área. Ainda, pode abranger usuários comuns para a constituição de uma operadora de plano de saúde.

- Consumo: cooperativas de consumo existem para viabilizar a compra coletiva de produtos ou serviços. Dessa maneira, os cooperados obtêm preços 
mais competitivos e poupam recursos, garantindo a sustentabilidade financeira de seus negócios.

- Infraestrutura: por fim, o ramo do cooperativismo de infraestrutura fornece imóveis, energia elétrica, rede de telefonia e outros serviços essenciais. Isso possibilita o acesso a uma estrutura básica para o crescimento econômico e produtivo dos pequenos associados.

\subsubsection{Gestão/ Administração}

De caráter operacional a gestão pode ser considerada um dos pilares da administração, sua função é garantir que todos os processos sejam executados conforme o previsto e impulsionar a empresa rumo às suas metas e objetivos de forma concreta e eficiente, sem negligenciar o fator humano. Ela dá os direcionamentos sobre onde e como chegar a determinado objetivo.

A gestão pode ser entendida como o processo de coordenação e integração de recursos, tendente à consecução dos objetivos estabelecidos, através do desempenho das atividades de planejamento, organização, direção e controle. Pode ser também assimilada a processo de trabalho com e através dos outros, a fim de se atingirem eficazmente os objetivos organizacionais traçados, utilizando-se eficientemente os recursos escassos, num contexto em constante mutação (Santos, 2008).

Criador da teoria clássica o engenheiro francês Jules Henri Fayol, classifica as funções básicas da Administração como: prever, organizar, comandar, coordenar e controlar.

Para que as organizações pudessem ganhar em eficácia, eficiência e crescimento, mais tarde, esses conceitos fundamentais foram alterados pelos estudiosos da teoria neoclássica, que unificaram alguns termos e revisaram algumas das nomenclaturas. Sendo assim, o termo dirigir; substituiu as terminologias, comandar e coordenar, já o prever foi alterado para planejar, gerando dessa forma as conhecidas PODC: planejar, organizar, dirigir e controlar. Planejar e organizar representam aspectos mais abstratos, enquanto dirigir e controlar caracterizam aspectos mais concretos. 
$\mathrm{Na}$ função Planejamento, podemos dizer que $\mathrm{o}$ ato de planejar compreende determinar a direção a ser seguida com o intuito de chegar ao resultado almejado (LACOMBE. HEILBORN, 2006. p. 162). Precisa-se pensar o que fazer, como e quando e por quem deverá ser feito. O Planejamento é uma das funções da Administração que define as estratégias e ações para que os objetivos especificados sejam alcançados através de atividades coordenadas (SOBRAL, 2013. p. 9). O Planejamento se divide em três partes, a saber, o estratégico que abrange toda a empresa. O Tático que é por departamentos e feito a médio prazo e o Planejamento Operacional que é elaborado para ação imediata, é para curto prazo, sendo aplicado a cada atividade.

Já a função Organização é aquela responsável por dividir as tarefas entre os membros da empresa (Sobral, 2013 p. 10). A estrutura organizacional é o resultado dessa função administrativa, pois ela agrupa as atividades de forma lógica. Ela define como os recursos, a autoridade e o trabalho serão distribuídos para que atinjam os objetivos planejados anteriormente de forma eficiente (Chiavenato 1993). A etapa de organização se refere à definição da construção estrutural organizacional de uma empresa, é o processo de dividir o trabalho, designar, agrupar e coordenar as atividades em cargos e áreas e alocar recursos de modo que a organização possa alcançar eficientemente seus objetivos.

A Direção é uma das fases do processo mais importante pois está diretamente ligada a liderança, motivação e coordenação. Ela integra tudo o que foi planejado e organizado gerindo as pessoas na organização. É a função administrativa que exige mais ação (LACOMBE. HEILBORN, 2006), pois é ela que faz coisas acontecerem, une os setores para chegar a um objetivo comum, harmoniza atos e esforços, envolve as teorias motivacionais, conduz as pessoas pela coordenação, pela liderança e pela comunicação.

Sendo a última, mas não menos importante função da administração, o Controle, que segundo Chiavenato (1979) tem por objetivo medir e corrigir, se necessário, atividades que por ventura saíram do eixo pré-estabelecido nas funções anteriores. O controle garante que todo o planejamento seja executado pelos subordinados acompanhando as ações, comparando resultados e fazendo as manobras necessárias durante ou após o percurso. Assim como o 
Planejamento, o Controle pode ser divido em estratégico, tático e operacional conforme a sua atuação.

Quando considerado de forma separada o PODC constitui funções administrativas, quando tomadas em conjunto para alcance de objetivos formam o processo administrativo. Este, viabiliza a ação administrativa dentro das organizações conduzindo racionalmente os recursos organizacionais pretendidos dentro dessa ação administrativa de funções administrativas que acontece de maneira sequencial ciclicamente e repetidamente.

É importante salientar que mesmo citando-as de forma sequencial, as funções administrativas estão inter-relacionadas e algumas delas podem ocorrer simultaneamente e sua aplicabilidade, serve para todos os tipos de organizações, seja o primeiro, segundo ou terceiro setor.

\subsubsection{Estrutura Organizacional de Cooperativa}

Dentre as diversas formas de gestão nas OTS, a autogestão e a gestão participativa são os modelos seguidos pelas Cooperativas.

A autogestão foi uma vitória do movimento cooperativista na promulgação da Constituição de 1988, impossibilitando a intervenção do Estado no sistema cooperativista, salvo a fornecer apoio técnico ou financeiro e para estabelecer, criar ou elaborar leis sobre o setor. No princípio a gestão acontece segundo vontade e anseios de seus administradores, podendo contratar "gerentes, técnicos ou comerciais", conforme o artigo 48 da lei Cooperativa. Segundo Barbosa (2010), o poder legislativo impetrou as associações cooperativas um modelo especial em administração, à autogestão.

Por serem os verdadeiros donos do negócio, é de total responsabilidade dos cooperados a gestão e fiscalização dessas entidades, tornando assim a sua gestão mais complexa do que as demais organizações. Para o Portal de Cooperativismo de Crédito (2014). As cooperativas são organizações democráticas, controladas por seus membros, que participam ativamente na formulação de suas políticas e na tornada de decisões. Esse processo, pelo qual 
são definidas linhas estratégicas, é chamado de "autogestão" e ocorre diariamente por meio da atuação constante dos associados na administração da cooperativa. Conscientes do seu papel como donos.

As cooperativas dispõem de dupla natureza, ela é uma associação de pessoas e ao mesmo tempo é uma empresa econômica. No papel de associação-cooperativa reúne pessoas que têm interesses comuns e como empresa-cooperativa, são administradas pelos mesmos princípios econômicos de qualquer organização. Segundo Valadares (2002a, p.33), a gestão de cooperativa apresenta dois aspectos: "[...] de um lado, o grupo cooperativo (a associação) e, de outro, a atividade cooperativa (a empresa), destinada ao serviço das economias individuais associadas".

Em uma cooperativa, devem existir pelo menos dois centros de decisão, o grupo de associados que tem sua participação atrelada ao poder do voto e os órgãos de direção, que Ihe são confiados, através da Assembleia Geral, poderes no processo administrativo, com a missão de assegurar a continuidade dos privilégios prestados, oferecer vantagens e serviços eficientes aos sócios, e a relação econômica do grupo com a empresa cooperativa.

Em sua essência, uma cooperativa tem objetivos sociais e econômicos, integrando pessoas na busca de uma vida melhor. Para que esta missão seja de fato cumprida, é necessário dar-lhe um caráter profissional desde seu planejamento. É de grande importância planejar, criar legalmente, organizar, dirigir e controlar uma organização cooperativa. Com a forte concorrência interna e externa, torna-se fundamental administrar de forma eficiente e eficaz esse tipo de organização para a consecução de seus objetivos (BÜTTENBENDER, 2011).

Nas cooperativas, as funções administrativas (planejamento, organização, direção e controle), estão intimamente ligadas ao Conselho Administrativo/Diretoria que é o órgão da estrutura organizacional que estabelece diretrizes para condução dos negócios relativos ao objeto da sociedade e que delibera sobre questões que envolvam a gestão da Cooperativa. Apesar de serem geridas pelo Conselho Administrativo, as ações desse órgão são analisadas pelos integrantes do Conselho fiscal e é de responsabilidade da Assembleia Geral, que é o órgão decisório maior do 
cooperativismo a aprovação ou rejeição do relatório gerencial, sempre por maioria simples de voto.

Uma estrutura organizacional se faz necessária para viabilizar esse processo, onde as atividades sejam divididas, organizadas e coordenadas, tornando claro a autoridade e as responsabilidades das pessoas, como indivíduos e como integrantes de grupos dentro das empresas. Refere-se ao modo como as atividades de uma organização são ordenadas para possibilitar o alcance dos objetivos. Essa estrutura especifica os papéis, as relações e os procedimentos organizacionais que possibilitam uma ação coordenada de seus membros.

Segundo o que estabelece a Lei ํㅡ 5.764/71, especialmente no seu artigo 47, "A sociedade será administrada por uma Diretoria ou Conselho de Administração, composto exclusivamente de associados eleitos pela Assembleia Geral, com mandato nunca superior a 4 (quatro) anos, sendo obrigatória a renovação de, no mínimo, 1/3 (um terço) do Conselho de Administração". E ainda: "Os órgãos de administração podem contratar gerentes técnicos ou comerciais, que não pertençam ao quadro de associados, fixando-lhes as atribuições e salários". Prescreve a lei específica que "o estatuto poderá criar outros órgãos necessários à administração". Qualquer que seja o ramo da cooperativa, "A administração da sociedade será fiscalizada, por um Conselho Fiscal, constituído de 3 (três) membros efetivos e 3 (três) suplentes, todos associados eleitos anualmente pela Assembleia Geral, sendo permitida apenas a reeleição de 1/3 (um terço) dos seus componentes".

Figura 1 - Estrutura Organizacional de uma cooperativa representada por um Organograma. 


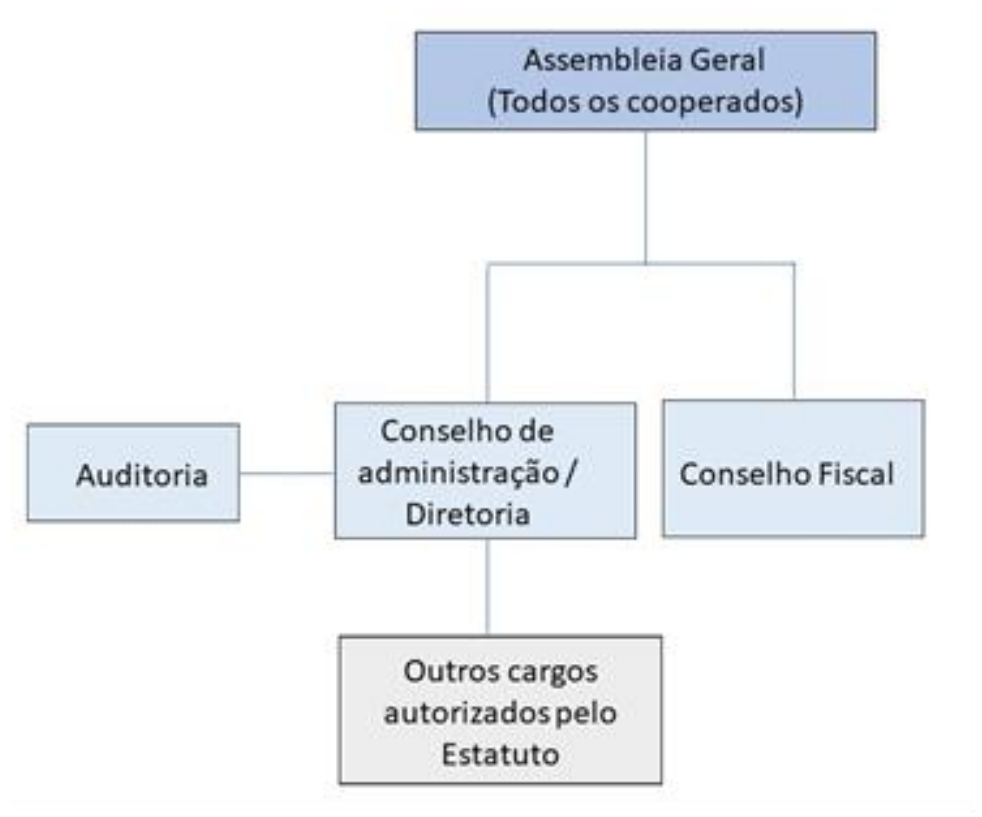

Elaborado pelo próprio autor deste estudo, 2021

A estrutura organizacional dessas organizações é formada basicamente pela Assembleia Geral, pelo Conselho de Administração e pelo Conselho Fiscal, que têm funções e atribuições especificadas no Estatuto Social.

\subsubsection{Cooperativa de Crédito}

Criada com o objetivo de atender aos seus colaboradores, proporcionandoIhes bens ou serviços e com expectativas diferentes das empresas comerciais, que têm o retorno financeiro como meta a ser alcançada, as cooperativas financeiras não possuem o propósito de obtenção de lucro e tão pouco produzem sobras. Dada a sua origem e propósito, o cooperativismo não visa lucros, assim os direitos e deveres de todos são iguais e a adesão é livre e voluntária (MEINEN, 2016).

Cooperativa de crédito é uma sociedade cujo capital é formado pelos associados e tem por objetivo a captação de recursos para realização de empréstimos aos seus cooperados via assistência creditícia. Disponibilizando aos seus associados, linhas de crédito com taxas de juros significativamente menores que as praticadas pelas demais organizações financeiras.

As cooperativas de crédito são associações de pessoas, que nela ingressam voluntariamente (tornando-se sócios) e que passam a fazer suas 
movimentações financeiras por meio dessas, e não mais com os bancos tradicionais. Estes sócios passam a serem os donos da cooperativa, juntamente com centenas ou milhares de outras pessoas (SESCOOP, 2016; MEINEN, 2016).

\subsubsection{Diferença entre cooperativa de crédito e bancos}

O funcionamento das cooperativas de crédito se assemelha ao procedimento de um banco comercial. Os mesmos serviços prestados por bancos comuns, como empréstimos, conta corrente, cartão de crédito, emissão de talões de cheque e tantos outros podem ser oferecidos pelas cooperativas de credito de maneiras mais simples.

Para Leite e Senra (2005, p. 174), as cooperativas de crédito possuem diferenças com relação aos bancos, conforme podemos verificar na Tabela 2 Diferenças entre uma Cooperativa de Crédito e as demais Instituições Financeiras.

Tabela 2 - Diferenças entre uma Cooperativa de Crédito e as demais Instituições Financeiras

\begin{tabular}{|c|c|}
\hline COOPERATIVA & BANCOS \\
\hline São sociedades de pessoas. & São sociedades de capital. \\
\hline Os usuários são associados. & Os usuários são clientes. \\
\hline $\begin{array}{c}\text { Todos participam da decisão da política } \\
\text { operacional. }\end{array}$ & $\begin{array}{c}\text { Os usuários não influenciam nos produtos } \\
\text { ou na precificação }\end{array}$ \\
\hline $\begin{array}{l}\text { Administra os recursos financeiros dos } \\
\text { associados de forma vantajosa para todos. }\end{array}$ & Visa o lucro. \\
\hline $\begin{array}{l}\text { Os resultados retornam aos sócios de } \\
\text { forma proporcional às operações realizadas. }\end{array}$ & $\begin{array}{l}\text { Os resultados retornam aos clientes } \\
\text { proporcionalmente ao número de ações }\end{array}$ \\
\hline $\begin{array}{l}\text { Compromisso é educacional, social e } \\
\text { econômico. }\end{array}$ & $\begin{array}{l}\text { Não tem por prioridades os investimentos } \\
\text { locais. }\end{array}$ \\
\hline
\end{tabular}

Fonte: https://www.sicoobcopermec.com.br/cooperativismo. Pág.2

O acesso fácil ao crédito é mais uma característica desse tipo de organização. As taxas de juros cobradas são mais baixas que as aplicadas pelos bancos comerciais, seu processo é menos burocrático e moroso, tornando-se mais eficiente. 
Afirma Pinheiro (2008) que o setor cooperativista é de singular importância para a sociedade, por promover a aplicação de recursos privados e assumir os riscos correspondentes em favor da comunidade em que se desenvolve. As cooperativas se constituem como uma associação de pessoas sem fins lucrativos, economicamente organizada e democrática, tendo como princípio a adesão livre e voluntária, a participação econômica e a gestão exercida pelos cooperados aos quais presta serviços. Por esse motivo, é razoável supor que as taxas de juros das operações concedidas por essas instituições sejam bastante competitivas, se comparadas às das operações similares concedidas por instituições financeiras bancárias.

Pinheiro (2008, p.7), as cooperativas de crédito são instituições financeiras constituídas sob a forma de sociedade cooperativa, tendo por objetivo a prestação de serviços financeiros aos associados. A seguir, um quadro comparativo as taxas de juros médias por modalidade de crédito cobradas pelas maiores cooperativas de crédito em relação às taxas praticadas pelos bancos.

Quadro 1 - Comparativo de taxas de juros médias por Modalidade de crédito:

Taxas médias de juros

\begin{tabular}{|c|c|c|c|}
\hline Modalidade de crédito & $\begin{array}{l}\text { Taxa de juros média } \\
\text { nos bancos }\end{array}$ & $\begin{array}{l}\text { Taxa de juros média } \\
\text { no Sicredi }\end{array}$ & $\begin{array}{l}\text { Taxa de juros média } \\
\text { no Sicoob }\end{array}$ \\
\hline Crédito pessoal & $6,08 \%$ ao mês & $3,41 \%$ ao mês & $1,71 \%$ ao mês \\
\hline Cheque especial & $12,40 \%$ ao mês & $7,61 \%$ ao mês & $6,52 \%$ ao mês \\
\hline $\begin{array}{l}\text { Cartão de crédito } \\
\text { rotativo }\end{array}$ & $12,67 \%$ ao mês & $11 \%$ ao mês & $8,40 \%$ ao mês \\
\hline $\begin{array}{l}\text { Cartão de crédito } \\
\text { parcelado }\end{array}$ & 8,92\% ao mês & $6,30 \%$ ao mês & $5,20 \%$ ao mês \\
\hline Crédito consignado & $1,57 \%$ ao mês & $1,62 \%$ ao mês & $1,43 \%$ ao mês \\
\hline $\begin{array}{l}\text { Financiamento de } \\
\text { veículo }\end{array}$ & $1,49 \%$ ao mês & 1,53\% ao mês & $1,29 \%$ ao mês \\
\hline
\end{tabular}

Fonte: Banco Central, Sicredi e Sicoob

Importante realçar que as cooperativas de crédito são supervisionadas pelo Banco Central, ao contrário de outras subdivisões do cooperativismo, como transporte e educação.

\subsection{Governança Corporativa}

A governanças corporativa são práticas adotadas, que tem como objetivo principal tornar o mais eficiente possível o desempenho das organizações. 
Para Silva (2012) "a governança corporativa é um conjunto de práticas que têm por finalidade otimizar o desempenho de uma companhia, protegendo investidores, empregados e credores, facilitando, assim, o acesso ao capital". Ela abrange o relacionamento entre os acionistas, o conselho, a diretoria e os órgãos de controle e fiscalização, além de assegurar a transparência das relações e a igualdade entre os envolvidos. Sempre prestando contas de forma ética, integra e transparente em tudo que a empresa realiza.

De acordo com o IBGC (Instituto Brasileiro de Governança Corporativa) órgão de referência para o assunto, governança corporativa é:

"Um sistema pelo qual as sociedades são dirigidas e monitoradas, envolvendo os acionistas e os cotistas, Conselho de Administração, Diretoria, Auditoria Independente e Conselho Fiscal. As boas práticas de governança corporativa têm a finalidade de aumentar o valor da sociedade, facilitar seu acesso ao capital e contribuir para a sua perenidade".

A governança corporativa é uma área de estudo com múltiplas atuações dentro de uma organização, uma de suas principais atenções é estimular a estratégia do alinhamento de interesses entre gestores e acionistas como modo de aperfeiçoar a gestão do negócio, resultando em maior transparência, segurança e confiabilidade entre os atores.

\subsubsection{Origem}

Na década de 1990, grandes escândalos contábeis foram os principais incentivadores do debate que levou ao surgimento das boas práticas de governança corporativa. Escândalos como da Eron nos Estados Unidos motivaram discussões envolvendo acadêmicos, legisladores e investidores, sempre em busca de caminhos para conter a situação.

A governança corporativa surgiu após o aparecimento de escândalos em grandes países entre a década de 80 e 90 . Foi com um movimento dos acionistas e investidores nos Estados Unidos que, para se protegerem dos abusos feitos pela diretoria executiva das empresas, da inercia dos conselhos de administração inoperantes e das omissões das auditorias externas, despertaram a busca por regras e criação de sistemas de monitoramento interno e externo 
que impedissem esses abusos das empresas perante seus investidores (IBGC, 2008).

O tema foi parar no congresso americano e surgiu a lei Sarbanes-Oxley (SOx), com definições fundamentais a respeito das práticas de governança corporativa. Em 1992, surgiu na Inglaterra o Relatório Cadbury, considerado o primeiro código de boas práticas de Governança Corporativa.

\subsubsection{Governança Corporativa no Mundo}

Nos últimos anos, a adoção das melhores práticas de governança corporativa tem se expandido por vários países, tanto os desenvolvidos como os em desenvolvimento, na busca de mais confiança dos investidores, se baseando nos princípios da transparência, independência e prestação de contas. A adoção das melhores práticas de governança corporativa exerce uma forte pressão para aceitação do sistema nos demais países.

\subsubsection{Governança Corporativa no Brasil}

No Brasil, através do protagonismo do Instituto Brasileiro de Conselheiros de Administração (IBCA), que a partir de 1999 passou a ser intitulado Instituto Brasileiro de Governança Corporativa (IBGC), a governança corporativa começou a ser preparada, dissipada por meio de livros, cursos, pesquisas, palestras e workshops por ele promovidos. O IBGC é uma entidade independente e dedicada ao desenvolvimento da Governança no Brasil.

No mesmo ano, é lançado no país, pelo próprio Instituto Brasileiro de Governança Corporativa (IBGC), o primeiro Código das Melhores Práticas de Governança Corporativa na adoção de condutas transparentes, responsáveis e imparciais na administração das organizações, visando melhorar seu desempenho e facilitar o acesso ao capital e incentivar a sua utilização. 


\subsubsection{Prática de Boa Governança Corporativa}

As boas práticas de governança corporativa vêm conquistando cada vez mais ambiente nas organizações contemporâneas voltadas para o futuro. Ela atinge tanto o mercado interno como o externo e vem sendo exigida cada vez mais pelo mercado, valorizando de forma significativa as ações das empresas, assegurando que os executivos alcancem as metas estipuladas pelo principal, e não seus particulares interesses.

Sua adoção é fator fundamental e indispensável no desenvolvimento econômico sustentável e melhorias no desempenho das empresas. Costumam ter maior facilidade para captar recursos, aperfeiçoando o controle, reduzindo custos, reprimindo diversos conflitos de interesses que podem ser críticos para uma organização. Tudo isso passa uma imagem de credibilidade para os investidores e segurança para os proprietários.

A adoção da boa prática de Governança na cooperativa garante a aplicação da autogestão no Sistema Cooperativista Nacional e tem por finalidades as ações descritas na tabela abaixo:

Tabela 3 - Práticas de Boa Governança

Ampliar a transparência da administração da sociedade cooperativa

Facilitar o desenvolvimento e a competitividade das cooperativas

Contribuir para a sustentabilidade e perenidade do modelo cooperativista

Aprimorar a participação do cooperado no processo decisório

Obter melhores resultados econômico-financeiros

Incentivar a inovação e proporcionar a melhoria da qualidade dos serviços ao quadro social

Aplicar a responsabilidade social como integração da cooperativa com a sociedade civil.

Ressalta-se que os princípios e práticas da boa Governança Corporativa aplicam-se a qualquer tipo de organização, independentemente do porte, natureza jurídica ou tipo de controle. 


\subsubsection{Princípios da Governança Corporativa}

As práticas da boa governança são baseadas em quatro princípios básicos fundamentais, conforme o IBGC que são:

1.Transparência: Mais do que a obrigação de informar é o desejo de disponibilizar para as partes interessadas as informações que sejam de seu interesse e não apenas aquelas impostas por disposições de leis ou regulamentos. A adequada transparência resulta em um clima de confiança, tanto internamente quanto nas relações da empresa com terceiros. Não deve restringir-se ao desempenho econômico-financeiro, contemplando também os demais fatores (inclusive intangíveis) que norteiam a ação gerencial e que conduzem a criação de valor.

2.Equidade: Tratamento justo de todos os sócios e demais partes interessadas (stakeholders), onde atitudes ou politicas discriminatórias, sob qualquer pretexto, são totalmente inaceitáveis.

3.Prestação de Contas: Os agentes de governança* devem prestar contas de sua atuação, assumindo integralmente as consequências de seus atos e omissões.

4.Responsabilidade Corporativa: Os agentes de governança devem zelar pela sustentabilidade das organizações, visando a sua longevidade, incorporando considerações de ordem social e ambiental na definição dos negócios e operações. Nota:* Agentes de governança refere-se aos sócios, administradores (conselheiros de administração e executivos/ gestores), conselheiros fiscais e auditores.

\subsubsection{Governança em Cooperativas de Crédito}

No Brasil, desde a publicação da Resolução do Conselho Monetário Nacional n. 3.859 de 27 de maio de 2010, as Cooperativas de Crédito estão obrigadas a implantarem a Governança Corporativa em sua gestão pelo Banco Central do Brasil [BACEN] (2010). 
Através das regulamentações exigidas pela Resolução CMN no 3.859/10, as cooperativas, foram obrigadas a aderir a algumas práticas de governança corporativa, a sua implementação viabiliza uma gestão mais profissionalizada e transparente, visando melhorar o desempenho e a sustentabilidade com base nos princípios e valores do cooperativismo.

O emprego da governança corporativa é de essencial importância para o desenvolvimento das cooperativas de crédito. Por se tratar de uma instituição do setor financeiro as Cooperativas de Créditos ficam expostas a um alto risco sistêmico, portanto precisa estar norteada por vários princípios de governança corporativa capazes de auxiliar positivamente o processo de gestão e assim alcançar o patamar de desempenho exigido pelo mercado.

\subsubsection{Diretrizes para as boas práticas da Governança Corporativa nas Cooperativas de Crédito}

O Banco Central do Brasil, através de seus servidores endossado por representantes do segmento de cooperativas de credito com o propósito de fortalecimento da governança em cooperativas de crédito no Brasil, lançou um projeto estratégico idealizado no intuito de disseminar as diretrizes para boas práticas de governança nessas instituições.

As diretrizes são recomendações gerais sobre governança que tem como objetivo sinalizar caminhos para que as cooperativas obtenham bons resultados em suas práticas. Por não possuir caráter normativo a aceitação às diretrizes é opcional.

\subsubsection{Estrutura das Diretrizes}

Idealizada com sustentação em estudo e pesquisas realizados em domínio do projeto governança coorporativa, as diretrizes estão divididas em quatro seções, que buscam evidenciar grupos de questões da governança, consideradas essenciais para as cooperativas. 


\subsubsection{Representatividade e participação}

Essa categoria ressalta a adesão de práticas específicas de governança corporativa, particularmente no que se refere à participação e a representatividade dos grupos componentes, no quadro social da cooperativa de crédito.

É Através da assembleia geral que os associados exercem a representatividade e participação tratando de temas de seus interesses, onde os mesmos têm o direito de estar discutindo e contribuindo nas decisões das cooperativas que é realizada uma vez por ano.

Através da aplicação de mecanismos de comunicação e de divulgação, os administradores das cooperativas devem estimular e assegurar a efetiva representação e participação dos associados nas assembleias, permitindo que eles se expressem e sejam escutados, pois representam um elemento fundamental de controle interno e orientação estratégica nesse tipo de organização. Por isso importância do envolvimento associativo nas cooperativas.

\subsubsection{Direção estratégica}

Previsto na lei, (Art. 142 da Lei 6.404/76 - Lei das Sociedades Anônimas), e recomendado pelo IBGC como boa prática de governança o Conselho de Administração/ Diretoria é um órgão colegiado, eleito pelos cooperados em Assembleia Geral Ordinária.

Por meio de Assembleia Geral, o órgão recebe poderes dos cooperados e presta contas a eles. Responsável pelo processo decisório das políticas e diretrizes gerais da cooperativa, o conselho também tem o poder de fiscalização e normatização.

Sua atribuição basicamente, é ser o representante dos acionistas, a ligação entre os cooperados e a gestão, para orientar e supervisionar a relação desta última com as demais partes interessadas, preservando os legítimos interesses comuns dos associados da cooperativa, seu objeto social e sua sustentabilidade no longo prazo. 
A missão do Conselho de Administração/Diretoria é proteger e valorizar o patrimônio, bem como maximizar o retorno do investimento econômico e social dos cooperados.

\subsubsection{Gestão Executiva}

Os profissionais que ocupam cargos de gestão executiva são responsáveis pela gestão operacional da cooperativa, ou seja, pela execução das estratégias que levem ao alcance das metas da instituição, além de estar em conformidade com a orientação geral traçada pelo Conselho de Administração/ Diretoria e devendo prestar contas de sua atuação a órgãos superiores, e para as instancias de auditoria. Faz parte de sua atuação ser o elo entre a Gestão e o Conselho de Administração, com dever de lealdade para com a cooperativa.

Cumprir e fazer cumprir o Estatuto, as deliberações da Assembleia Geral e do Conselho de Administração, bem como avaliar as recomendações do Conselho Fiscal, estar entre seus papéis. O Estatuto da cooperativa deve prever as competências dos diretores, as atribuições e as responsabilidades dos administradores com funções, inclusive as exigências quanto a sua formação e experiência tornando-os qualificados para o exercício da função.

\subsubsection{Fiscalização e Controle}

A fiscalização e o controle nas cooperativas além de necessários, são de suma importância para a realização de boas práticas de governança corporativa e desempenham papel fundamental na governança dessas entidades.

Se destacam como agentes e órgãos para este monitoramento: Associados; Conselho Fiscal; Auditoria Interna e Externa.

\subsubsection{Associados}

O cooperado como proprietário e usufruidor é a parte mais interessada nos negócios da cooperativa, logo, deve portar-se como instrumento eficiente de fiscalização e controle da organização. 
Os associados são as pessoas que tem direito a voto, contribuem para a formação do capital social da cooperativa, goza de direitos e obrigações e deve agir como ferramenta determinante na verificação e a apuração do controle da organização, são, ao mesmo tempo, proprietários e usuários da sociedade, é da obrigação da administração criar estrutura para garantir sua participação e para que tenha conhecimento de seus direitos, deveres legais e estatutários, especialmente em casos de perda e/ou prejuízo.

\subsubsection{Auditorias}

A auditoria é um importante agente no controle e fiscalização nas cooperativas, contribui com a melhoria na governança corporativa, e será igualmente um considerável suporte de proteção aos associados das cooperativas de crédito. Uma das suas colaborações é diminuir a diferença de informação, ao comparar a autenticidade dos dados informados nos relatórios gerenciais econômicas e financeiras, encaminhado ao Conselho Fiscal e Conselho de Administração.

Existem dois tipos de auditoria que são de grande importância para a fiscalização, e para que as cooperativas de créditos possam ser constituídas. A auditoria pode ser classificada em: Auditoria Interna e Auditoria Externa.

\section{Auditoria Interna}

A Auditoria Interna é um importante instrumento de fiscalização e controle gerencial, relevante para instituições de todos os portes e apresenta papel imprescindível como um dos alicerces da solidez da governança corporativa das instituições financeiras. Deve avaliar de forma independente, autônoma e imparcial a qualidade e a efetividade dos sistemas e processos de controles internos, de gerenciamento de riscos e de governança corporativa da instituição.

Através de sua atividade se torna um recurso gerencial indispensável aos gestores das organizações, sendo capaz de estabelecer de modo claro, recomendação do aprimoramento dos controles internos, das normas e se os 
procedimentos internos estão adequados as normas internas e externas vigentes, em acordo com as melhores práticas pertinente à atividade.

Uma de sua atribuição é indicar que a gestão esteja ciente dos pontos falhos para que eles sejam reparados e consequentemente os gestores possam desempenhar eficazmente suas atividades para a tomada de decisões, orientando-se correções e adequações quando possível e necessário.

\section{Auditoria Externa}

A figura de uma auditoria externa na governança corporativa é de grande relevância, toda cooperativa deve ter suas demonstrações financeiras auditadas por auditor externo independente.

Sua ação é benéfica para a credibilidade das demonstrações contábeis e financeiras e confiabilidade das informações em relação à gestão, com averiguações imparciais e capacidade técnica para avaliar os relatórios financeiros e visão estratégica.

A auditoria externa deve ser elaborada por um auditor independente, sem laço algum com a empresa auditada, permitindo ao auditor externo emitir com lisura a real situação econômica e financeira da cooperativa.

\subsubsection{Relatório de Auditoria}

O relatório de auditoria é o acervo dos trabalhos executados pela auditoria. Neles são manifestados opiniões e entendimentos sobre o estado patrimonial da cooperativa auditada e o formato de exposição dos resultados, de forma clara, completa, objetiva, independente e imparcial.

Os relatórios devem ser fiéis e completo, para assim refletirem os fatos ocorridos na empresa auditada, devidamente comprováveis através dos papeis de trabalho. É a partir dos relatórios que o auditor expressa a sua opinião e emite o parecer sobre as demonstrações financeiras. 


\subsubsection{Conselho Fiscal}

Considerado fundamental e obrigatório na estrutura de controle do sistema cooperativo, e na figura de elo entre os cooperados e o restante da cooperativa, o conselho fiscal, como o nome sugere, tem a função de supervisionar as ações dos administradores e opinar sobre demonstrações financeiras, balancetes e contas de modo geral.

Deve ser órgão independente da administração da cooperativa, assim assegurar efetiva transparência dos negócios. É de responsabilidade do conselho oferecer contas de suas atividades aos cooperados, com o intuito de permitir-Ihes um bom discernimento e uma opinião das ações do órgão. Sua eficiência depende de sua autonomia e isenção para extrair informações importantes ao cumprimento dos seus trabalhos.

Esse órgão tem como função principal além do fiscalizar, verificar os atos administrativos, identificando se a atuação desses agentes condiz com os interesses dos associados e demais partes relacionadas, sinalizando qualquer tipo de irregularidade ou fraude que descobrir. Para que isso ocorra à capacidade de fiscalização do conselheiro fiscal deve ser a mais ampla possível, devendo estar subordinado exclusivamente à Assembleia Geral, assim está fora do conflito de interesse entre órgãos de administração.

\subsubsection{Organização Sistêmica}

Em todas as partes do mundo, as cooperativas de créditos buscam se organizar e fortalecer de maneira integrada dentro de uma estrutura sistêmica, solidário e com valores e princípios idênticos, , associadas a outras cooperativas, gerando diferentes instituições de grau superior, como centrais, confederações, bancos cooperativos, e centros de serviços integrados, com o objetivo de auxiliar na supervisão e regulação dessas instituições, favorecendo a boa governança dessas entidades, de forma mais fundamentada e diferenciada.

A organização sistêmica tem por objetivo reforçar a relevância e a colaboração de um exigente sistema de controle e de regulação de boa 
governança e segurança de todo o segmento, aperfeiçoa o comando das funções de cada colaborador e gestor em uma cooperativa.

Frisando que a atuação da confederação ou sistema organizado não exime a obrigação das centrais e singulares pelo exercício individual das boas práticas de governança. 


\section{Metodologia}

$\mathrm{Na}$ metodologia serão listados e demonstrados os métodos, ferramentas fundamentais para a realização do trabalho e seu respectivo desenvolvimento.

\subsection{Método Dialético}

Segundo Vergara (1998, pág. 12) método é um caminho, uma forma, uma lógica de pensamento. Basicamente, há três grandes métodos: (a) hipotéticodedutivo; (b) fenomenológico; (c) dialético.

A pesquisa tem o método dialético como lente orientadora do processo de investigação, pois este permite compreender a processualidade da realidade social.

A sua escolha se deu por levar em consideração a contradição e o conflito, com o foco no processo, trabalhando conceitos próprios dessa metodologia, como totalidade, contradição, mediação, superação.

A dialética fornece as bases para uma interpretação dinâmica e totalizante da realidade, já que estabelece que os fatos sociais não podem ser entendidos quando considerados isoladamente, abstraídos de suas influências políticas, econômicas, culturais etc. Por outro lado, como a dialética privilegia as mudanças qualitativas, opõe-se naturalmente a qualquer modo de pensar em que a ordem quantitativa se torne norma (Gil, 2008, pag.14).

\subsection{Classificação da pesquisa}

Para a classificação da pesquisa, será adotada a tipologia de Vergara (1988, pag.44), discriminando suas características quanto aos fins e aos meios. 


\subsubsection{Quanto aos fins}

Usarei a pesquisa exploratória através de uma abordagem qualitativa. A pesquisa exploratória, por proporcionar em tese uma maior proximidade com o problema, com vistas a torná-lo mais explícito ou construir hipóteses, já a abordagem qualitativa, por não se preocupar com a representatividade numérica, mas, sim, com o aprofundamento da compreensão de um grupo social, de uma organização, etc.

Segundo Gil, (2008, pag. 27), "Muitas vezes as pesquisas exploratórias constituem a primeira etapa de uma investigação mais ampla. Quando o tema escolhido é bastante genérico, tornam-se necessários seu esclarecimento e delimitação, o que exige revisão da literatura, discussão com especialistas e outros procedimentos. O produto final deste processo passa a ser um problema mais esclarecido, passível de investigação mediante procedimentos mais sistematizados".

\subsubsection{Quanto aos meios}

Na pesquisa será empregada a estratégia do estudo de caso, pois permite um investigação minuciosa da realidade, partindo-se da experiência de uma unidade concreta, seja ela uma instituição, um sistema, um programa, uma pessoa etc., e em seguida, apurar o universo das possibilidades teóricas subjacentes que orientam a solução ou as soluções possíveis decorrentes do problema apresentado.

Estudo de caso é o circunscrito a uma ou poucas unidades, entendidas essas como uma pessoa, uma família, um produto, uma empresa, um órgão público, uma comunidade ou mesmo um país. Tem caráter de profundidade $\mathrm{e}$ detalhamento. Pode ou não ser realizado no campo (Vergara 1988, pag.44).

De acordo com Yin (2005, p. 32), o estudo de caso é um estudo empírico que investiga um fenômeno atual dentro do seu contexto de realidade, quando as fronteiras entre o fenômeno e o contexto não são claramente definidas e no qual são utilizadas várias fontes de evidência. 
$\mathrm{Na}$ construção deste estudo foi realizada uma investigação bibliográfica em estudos e trabalhos acadêmicos que abordam fundamentalmente as práticas de governança corporativa em cooperativas. Foram lidos artigos, monografias e sites de órgãos institucionais, ambos relacionados ao tema pesquisado. 


\section{Apresentação e análise dos resultados}

Este estudo de caso foi realizado na Coopcred-Ensino, com sede na Rua Marquês de São Vicente, 225 casas 14 - Parte - Gávea (PUC-Rio), com o objetivo de identificar como as principais práticas de governança adotadas por uma cooperativa de credito de ensino, de acordo com Manual de Boas Práticas de Governança, pode contribuir para as Cooperativas de Crédito.

Em seguida serão ressaltadas algumas das diretrizes aplicadas na Coopcred-Ensino, demostrando as contribuições da boa governança corporativa na Cooperativa de crédito em estudo.

\subsection{Apresentação da Cooperativa estudada}

De acordo com o estatuto social, Art. I, a cooperativa de crédito em estudo, foi instituída em Assembleia Geral, em 28/07/1974, com 36 associados, mas somente liberada para atuar em 14 /02/1975, pelo Banco Central. Como critério, para pertencer ao quadro associativo, somente professores e funcionários, da PUC-Rio.

Atualmente a Coopcred-Ensino conta com um quadro social composto de mais de 1221 associados, constituído de empregados da PUC-Rio, e de diversos estabelecimentos de ensino privado do município do Rio de Janeiro, composto de profissionais ligados à Prestação de Serviços de educação, tais como: professores, pedagogos, funcionários, administrativos etc. preponderantemente, e classificados como profissionais de estabelecimentos de ensino e professores, que é a sua atividade fim, além de profissionais de diversas atividades e formações que dão suporte à atividade principal.

Com uma atividade de complexidade simples, a Coopcred-Ensino, é considerada de porte médio, conta com uma estrutura operacional enxuta, composta de 2 funcionárias com a função de assistentes administrativas, 1 funcionária com a função de auxiliar administrativa e 1 funcionária com a função 
de auxiliar de escritório; prestadores de serviços sem vínculo empregatício na área contábil; informática; assessoria jurídica; auditoria interna e auditoria cooperativa.

A Coopcred-Ensino tem por objeto social o desenvolvimento de programa de poupança; de uso adequado do crédito e de prestação de serviços, praticando todas as operações ativas, passivas e acessórias próprias de cooperativas de crédito; proporcionar, através da mutualidade, assistência financeira aos associados em suas atividades específicas, formação educacional de seus associados, no sentido de fomentar o cooperativismo.

A sua Capitalização ocorre mensalmente através da folha de pagamento com o com desconto autorizado pelo associado no ato de sua adesão, com exceção dos aposentados e terceiros que depositam o valor nas contas bancárias da Cooperativa.

A solicitação de empréstimo é feita pelo próprio associado, o mesmo deverá informa o valor e o número de vezes que ele pretende pagar por mês. $O$ valor que será descontado mensalmente é submetido à análise do $\mathrm{RH}$ que em até 48 horas informa a Cooperativa a margem do funcionário, autorizando ou negando em caso falta de margem, após a análise do $\mathrm{RH}$ a liberação do valor do empréstimo ficará a critério da Diretoria.

A estrutura organizacional da cooperativa em estudo está representada na figura 2 a seguir: 
FIGURA 2 - Estrutura Organizacional da Coopcred

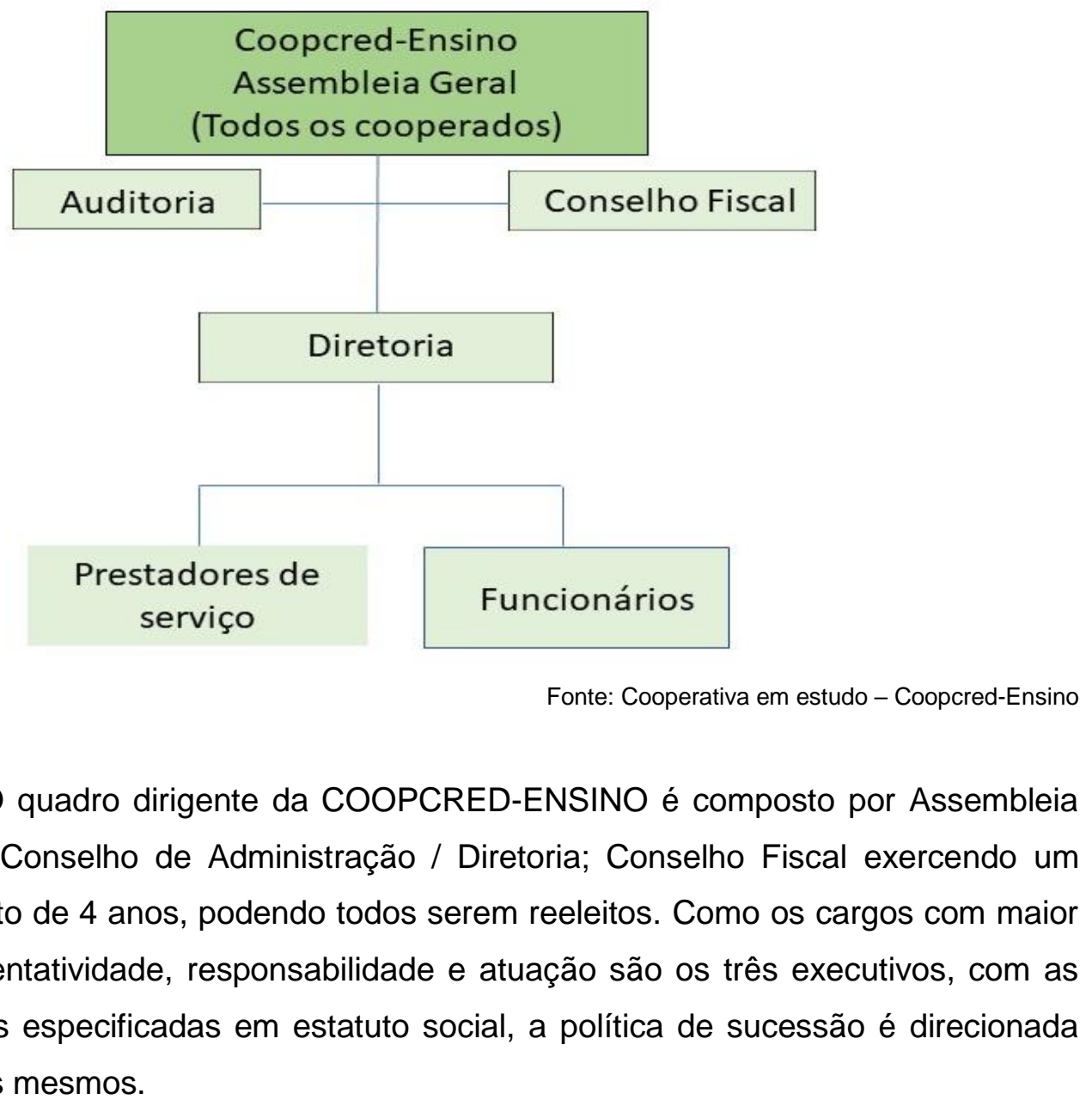

Área de atuação de cada diretor:

Diretor-Presidente:

- Gerenciamento de Risco de mercado;

- Gerenciamento do Risco de crédito;

- Gerenciamento de Risco;

- Política segurança cibernética.

Diretor Secretário:

- Gerenciamento de riscos;

- Risco operacional;

- Cumprimento da PRSA (Política de Responsabilidade Social);

- Cooperativas Filiadas;

- Área contábil; 
Diretor Administrativo:

- Resp. prevenção lavagem de dinheiro;

- Diretor resp. p/política relacionamento com clientes.

Diretor Operacional:

- Responsável pelo SCR - (Solicitação de Assinatura de Certificado)

- Resp. p/ atualização dados no UNICAD;

- Resp. p/operações emp. e troca de títulos;

- Resp. pelo fornecimento de informações;

- Resp. p/ operações de cessão de créditos.

Diretor:

- Diretor responsável pelas contas de depósitos;

- Risco de Liquidez;

- Informações - Consórcios;

- Diretor responsável pela Ouvidoria.

Conselho Fiscal:

- Três Conselheiros Fiscais Efetivos.

- Três Conselheiros Fiscais Suplentes.

\subsection{Análise e Diagnóstico}

\subsubsection{Participação na Cooperativa}

Segundo o modelo das diretrizes sugeridas pelo BACEN, a participação dos associados na cooperativa deve ser estimulada, viabilizando espaços para a manifestação de seus interesses, criando instrumentos que permitam que eles se expressem e sejam ouvidos, e assim potencializa a capacidade de pertencimento, propriedade e capacidade de influenciar os rumos da cooperativa, fortalecendo-se, assim, o princípio da gestão democrática. 
$\mathrm{Na}$ entrevista realizada com o Diretor Administrativo da Coopcred-Ensino, foram perguntadas as três maneiras que permite uma interação mais efetiva dos associados com a cooperativa, para expressarem sua opinião.

A mais utilizada, segundo o entrevistado é a conversa presencial com os diretores, na iminência da COVID, o seu Whatzapp pessoal foi um elo de comunicação entre a direção e o associado, o e-mail é o segundo mais utilizado e a caixa de sugestão na sede vem a seguir.

O feedback é um indicador ao estimulo da cooperativa da participação dos associados que usa tanto o canal formal quanto ao informal para interagir com a Cooperativa, mesmo nos momentos de maior dificuldade e limitações de locomoção devido a Pandemia, contribuindo para melhorar a gestão democrática, com a participação dos associados na formulação de políticas e na tomada de decisões.

\subsubsection{Assembleias Gerais}

Seguindo o regimento interno da Coopcred-Ensino exercida a sua ação pelos órgãos sociais, a Assembleia Geral ordinária ou extraordinária, é o órgão supremo da cooperativa, tendo poderes dentro dos limites da lei e deste estatuto para tomar toda e qualquer decisão de interesse social. As decisões tomadas em Assembleia Geral vinculam a todos os associados, ainda que ausentes ou discordantes.

No estatuto que rege a Coopcred-Ensino, cedido pela direção para fins desse estudo, consta que a data, hora e local são divulgados aos associados com um mês de antecedência da Assembleia Geral, através de edital, de forma a facilitar a presença dos associados, contribuindo para que haja maior representatividade dos interessados, diminuindo as dificuldades de deslocamento e a compatibilidade com outros compromissos.

Os trabalhos da assembleia geral serão habitualmente dirigidos pelo Diretor Presidente, auxiliado pelo Diretor Administrativo, que lavrará a ata, podendo ser convidados a participar da mesa os demais ocupantes de cargos estatutários. 
Os assuntos colocados em pauta na Assembleia Geral devem seguir definições pré-determinadas, antecipando assim o posicionamento e as opiniões dos associados. A pauta é desenvolvida em detalhes e com antecedência contribuindo para que os associados tenham maior compreensão dos assuntos constados na mesma no momento da votação de cada deliberação.

As decisões serão tomadas pelo voto pessoal dos presentes, com direito a votar, tendo cada associado um voto, vedada à representação por meio de mandatários. Em princípio, a votação será a descoberto, mas a assembleia geral poderá optar pelo voto secreto.

Em entrevistas semiestruturadas, o Diretor Administrativo, questionado se a cooperativa dispõe de mecanismos formal, que permitam, aos associados, inserirem itens na pauta das Assembleias Gerais previamente à sua realização, conforme as recomendações do BACEN, a diretoria cita que além da lei 5764/71 e o estatuto social permite a inclusão de pontos de pauta por parte dos associados, isso não é uma prática recorrente, "mas se a diretoria aceitar pode sim".

No que se refere a ata da Assembleia Geral, foi passado que a mesma é transparente, relatando todos os fatos ocorridos e as deliberações dos associados, e está acessível a todos os interessados. Cita também o incentivo da direção em assegurar a efetiva representatividade e participação dos associados nas deliberações da Assembleia Geral, de acordo com as recomendações do BACEN.

Conforme estatuto social da cooperativa, a Assembleia Geral Ordinária acontece uma vez ao ano, junto com a prestação de contas, precedida da leitura dos pareceres da auditoria externa e do Conselho Fiscal. A Assembleia Geral Extraordinária será realizada sempre que necessário e poderá deliberar sobre qualquer assunto de interesse da cooperativa, desde que mencionado no edital de convocação.

Através de informações de fontes documentais da cooperativa, como as atas das assembleias gerais, a presença dos cooperados da cooperativa de credito em estudo, é pouco expressiva e tem a participação média fica abaixo de $5 \%$ dos associados, esse número é muito pequeno comparado a importância da 
participação dos membros para a tomada de decisões, pois por serem os verdadeiros donos, não exercem o direito constitucional de decidir os negócios relativos aos objetivos da cooperativa. Assembleia Geral, por ser um órgão soberano, trata-se do momento em que serão tomadas as decisões da sociedade, mas para isso é preciso participação, influenciando então na tomada de decisão da Cooperativa de Crédito.

\subsubsection{Apresentação de resultados e eleições}

A intenção da Política de Sucessão de Administradores que consta nas normas internas da cooperativa em estudo é que os cargos executivos de diretoria sejam ocupados por profissionais qualificados e identificados com os valores da cooperativa. Outro ponto forte é o de assegurar que o Rodízio de Funções crie oportunidades de desenvolvimento profissional, com a preparação para novos desafios, de modo a garantir a continuidade dos negócios.

A Política de Sucessão levará em consideração as seguintes abrangências:

- Recrutamento - com a escolha de Candidatos à sucessão dentro do quadro social;

- Promoção - a divulgação prévia dos nomes dos futuros sucessores escolhidos, de modo a torná-los conhecidos ao quadro social, de modo a favorecer suas aceitações;

- Eleição - promover ações que possibilitem os mesmos serem eleitos nos pleitos a que concorrerem;

- Retenção - promover ações para que os sucessores eleitos permaneçam nos cargos para os quais forem eleitos, de modo que as suas gestões alcancem os objetivos traçados.

Requisitos

1) Os requisitos para o recrutamento e a seleção dos candidatos alvos para a Política de Sucessores, deverá levar em consideração os seguintes aspectos:

- Capacidade Técnica;

- Capacidade Gerencial;

- Habilidade Interpessoal; 
- Conhecimento da Legislação e da regulamentação relativas à responsabilização de qualquer natureza por sua atuação, e - experiência.

2) Como na prática, muitos dos requisitos enumerados podem não ser encontrados nos candidatos, tais como conhecimento da legislação e experiência efetiva na atividade da COOPCRED-ENSINO, esses requisitos serão desenvolvidos com a ajuda e o estímulo da cooperativa aos candidatos escolhidos.

3) Para a identificação dos candidatos à Política de Sucessão, serão levados em consideração os seguintes pré-requisitos:

- Quais os candidatos apresentam os pré-requisitos no grau mais indicado que o cargo exige;

- Quais os candidatos entregam resultados a mais que os cargos exigem;

- Quais candidatos apresentam perfis de liderança em grau mais elevado do que aqueles que ocupam;

- Quais candidatos detêm conhecimentos ou habilidades difíceis de encontrar em outro profissional no mercado;

Essa Política de Sucessão de Administradores deve ser objeto de revisão a qualquer tempo, ou no mínimo a cada 5 anos, de modo a torná-la sempre atual e compatível com as exigências de poder formar e contar com dirigentes capazes de assegurar a continuidade dos negócios,

As diretrizes sugeridas pelo BACEN, sinaliza que é desejável que os candidatos atendam a condições mínimas para se candidatarem, portanto, as práticas adotadas pela cooperativa de crédito em estudo no que se refere Política de Sucessão de Administradores, vai ao encontro das normas do BACEN.

\subsubsection{Auditoria}

A auditoria interna é uma atividade independente e objetiva de avaliação, sua atividade interna permanecerá livre de interferência de qualquer elemento da Cooperativa para permitir a manutenção de uma atitude mental necessária de independência e objetividade. 
Segundo as normas internas da Coopcred-Ensino, e de acordo diretrizes propostas pelo BACEN é da responsabilidade da administração da cooperativa:

- Indicar a contratação da Auditoria Interna;

- Aprovar o Regulamento Interno da Auditoria Interna;

- Submeter à aprovação pela Assembleia Geral o Regulamento Interno da Auditoria Interna;

- Aprovar o Plano Anual da Auditoria Interna;

- Avaliar e aprovar todas as decisões relacionadas à avaliação de desempenho da Auditoria Interna.

A Auditoria Interna da Coopcred-Ensino, é realizada pela Empresa de Auditoria Independente Mandarino \& Associados Auditores, conforme preconizado na Resolução 4.588, de 29 de junho de 2017, do Banco Central do Brasil.

O relatório de auditoria é encaminhado a todos os órgãos estatutários da cooperativa, contribuindo para que os órgãos devidos possam se manter informados e possam tomar as devidas providências.

A presença de uma auditoria interna efetiva e abrangente executada por profissionais adequadamente treinados, competente e operacionalmente independentes também são fatores consideráveis que caracterizam um bom controle interno e externo.

\subsubsection{Conselho Fiscal}

Seguindo o mesmo sentido das propostas de diretrizes do BACEM, o Conselho Fiscal é um órgão totalmente independente da administração da Coopcred-Ensino, sua forma de contribuição é fiscalizá-la como representante dos interesses dos associados no desempenho de funções e verifica as obrigações legais e estatutárias e o exame da gestão e dos atos que tenham impacto sobre os resultados da cooperativa, contribuindo para aumentar a segurança dos associados e converge com as práticas de boa governança. 
De acordo com o estatuto social da Coopcred-Ensino, as regras de funcionamento do Conselho Fiscal estão formalizadas nos normativos da cooperativa, seguindo as orientações do BACEM.

O conselho fiscal deverá ser formado por três membros efetivos e três membros suplentes, uma das características mínimas para se candidatar ao Conselho Fiscal, todos os postulante ao cargo devem pertencer ao quadro associativo e não ter negócios com a cooperativa além daqueles realizados na condição de associados e nem fazer parte do seu conselho de administração, é "aconselhável" que o candidato entenda de administração, contabilidade ou economia, dado a importante para ler os relatórios do balancete entre outros documentos.

A eleição do conselho fiscal da cooperativa decorre de forma individual e não por chapa, sendo empossados os candidatos mais votados, a fim de favorecer a independência do órgão, seguindo as diretrizes de boa prática de governança, mantendo o mandato pelo período de três anos, com direito a uma reeleição.

É uma pratica adotada pela cooperativa, que seus administradores com funções executivas disponibiliza além de documentos em tempo hábil para que os conselheiros fiscais possam analisa-los dentro dos prazos estabelecidos, cursos aos seus integrantes, com a finalidade de preparar os conselheiros para o exercício de suas funções de forma mais adequada, contribuindo para eficácia de seus serviços prestados como: fiscalizar os atos dos administradores e verificar o cumprimento de seus deveres legais e estatutários, pois se os mesmos não possuem estas características como a cooperativa vai assegurar a prestação de bons serviços.

\subsubsection{Conselho de Administração}

O quadro dirigente da Coopcred-Ensino é composto de 1 Diretor Presidente; 1 Diretor Administrativo; 1 Diretor Operacional; 1 Diretor Secretário; 1 Diretor sem funções específicas; para exercerem um mandato de 4 anos, podendo todos serem reeleitos. Como os cargos com maior representatividade; responsabilidade e atuação são os três executivos, com as funções 
especificadas em estatuto social, a Política de Sucessão é direcionada para os mesmos.

Recomendado pelo IBGC, como boa prática de governança, o Conselho de Administração/ Diretoria é um órgão colegiado, eleito pelos cooperados em Assembleia Geral Ordinária, Previsto na lei, (Art. 142 da Lei 6.404/76 - Lei das Sociedades Anônimas). O IBGC (2015b) indica a dualidade de cargos como uma condição para boas práticas.

Entretanto a Assembleia Geral pode optar por uma Diretoria eleita, que exerce tanto a função de direção estratégica como a função executiva, é o caso da cooperativa em análise, ou por um Conselho de Administração eleito - nesse caso, poderão ser escolhidos membros do conselho para desempenhar a função executiva ou poderão ser contratados profissionais (diretores) de mercado.

Apesar do quadro diretivo apresentar designação específica para cada um dos 5 diretores, através da observação nada indica uma separação desse quadro por especificidade operacional, os 5 diretores que se reúnem para tratar de assuntos mais diversos de interesse da cooperativa, estariam inseridos no Conselho de administração, não configurando assim a segregação de funções entre Diretoria Executiva e Conselho Administração.

De acordo com BACEM (2010), deve haver clara separação entre os papéis desempenhados pelos administradores com funções estratégicas (conselho de administração ou diretoria) e por aqueles com funções executivas (diretoria executiva, superintendência ou gerência).

\subsubsection{Código de conduta e padrões éticos}

A Coopcred-Ensino dispõe de código de Ética e Conduta, que visa a evidenciar e a reforçar os seus valores éticos da sua identidade organizacional como Cooperativa de Crédito integrante do Sistema Financeiro Nacional, e os princípios que orientam a condução de suas atividades. Os requisitos constam nos normativos da cooperativa, visto que são supervisionadas pelo BACEN. 
Este documento estabelece os princípios e as normas que definem as práticas de atuação da cooperativa e deve ser observado pelos membros estatutários eleitos da diretoria e do Conselho Fiscal, Funcionários, Prestadores de Serviços e serve como um guia de referência para todos os integrantes, com objetivo de nortear quanto a conduta aceita pela sociedade, agindo de boa fé e resguardando a cooperativa e os colaboradores de eventuais denúncias.

Todos os destinatários elencados devem utilizar as disposições previstas neste código como referencial ético e de conduta a ser observado no seu relacionamento com a Cooperativa e na condução de suas atividades em qualquer localidade na área de atuação da mesma.

\subsubsection{Ouvidoria}

A cooperativa dispõe de um canal de comunicação com o associado através de um telefone 0800 em convênio com a Federação Nacional das Cooperativas de Crédito Urbano - FENACRED, para mediação de conflitos.

O Ouvidor recebe a ligação, registra a eventual reclamação ou sugestão do cooperado, gerando um número de protocolo do atendimento, encaminha a mesma para o Diretor de Ouvidoria, que faz a análise da situação, dando resposta conclusiva ao Ouvidor que a repassará ao Cooperado.

O Ouvidor tem um prazo de 10 dias corridos a contar da data do atendimento para dar uma posição ao Cooperado e um relatório com as demandas e conclusões que fica arquivado na Cooperativa.

É designado pela Diretoria da cooperativa um Diretor Responsável e um ouvidor, ambos devidamente certificados, que irá executar as atribuições da ouvidoria.

\subsubsection{Sobras}

Sobras são sempre a diferença ao fechamento de um ano Fiscal relacionado a seu início, pode ser positiva ou negativa e seu destino é soberana a assembleia geral. No caso especifico da cooperativa de crédito, onde o que se 
vende é dinheiro, ao fim de cada ano fiscal é calculado através de balanço o custo de se manter a cooperativa e seus negócios $X$ o que a cooperativa obteve de receitas. A sobra é o delta positivo/negativo.

Critérios da Cooperativa: A diretoria da Coopcred-Ensino submete a Assembleia Geral a incorporação das sobras líquidas ao Fundo de Reserva, de modo a prevenir resultados negativos a que está sujeita.

Normas vigentes:

- As sobras líquidas apuradas serão transferidas para o título sobras ou perdas acumuladas, cujo saldo, ao final do exercício social, "se credor", será destinado, conforme deliberação da assembleia geral: (Circular BACEN $3.314 / 2006$ - art. 30)

- As sobras líquidas apuradas serão transferidas para o título sobras ou perdas acumuladas, cujo saldo, ao final do exercício social, "se devedor", será destinado, conforme deliberação da assembleia geral: (Circular BACEN $3.314 / 2006$ - art. 40).

Caso a assembleia resolva por ratear os "lucros" economizados naquele ano fiscal assim será feito, o total dividido pelo número de associados efetivamente detentores desse direito. Caso seja aprovado em assembleia, o prejuízo também poderá ser rateado (art. 80 da Lei complementar 130/2009). O que normalmente ocorre na cooperativa estudada é a diretoria, propor que os lucros sejam destinados a determinada festividade a que todos os cooperativados terão acesso sem pagar nada ou a custo simbólico conforme.

\subsection{Outras informações relevantes}

No estudo da cooperativa de crédito em questão baseado em conversas formais e informais e documentos disponibilizados pela direção e na participação de algumas reuniões de maneira informal, cito aqui no meu entendimento, o que considero os pontos fortes e os pontos fracos da Coopcred-Ensino.

Nota-se a forte relação que a diretoria da Coopcred-Ensino possui com os associados devido à proximidade entre os atores, pois trabalham na mesma 
empresa criando um vínculo afetivo entre eles. A troca de números de celulares, o uso do WhatsApp pessoal torna essa aproximação ainda mais forte, pois problemas, em sua maioria relacionados a empréstimos, podem ser parcialmente resolvidos com orientações técnicas diferenciadas para cada caso. Esse tipo de ação causa a sensação de pertencimento por parte do cooperado.

O atendimento diferenciado dos funcionários que trabalham no acolhimento aos associados, é um outro ponto positivo na Coopcred-Ensino. Ter uma pessoa exclusiva, treinada e cobrada pela Diretoria para melhor atender o cooperado, sem os imbróglios típicos das agências bancárias, torna esse momento menos aflitivo na vida do cooperado.

O cafezinho, o sorriso, a presteza, a desburocratização do atendimento com perguntas simples e objetivas, de forma a nunca constranger o associado é a base do atendimento na sede da Cooperativa, diferentemente do que ocorre em bancos comerciais, onde o cliente é visto através de cifras. No atendimento na cooperativa, todos os associados são clientes personalizados e a pouca rotação dos atendentes no tocante a tempo de serviço, cria um outro elo de afeição no atendimento, pois os associados e os prestadores de serviços acabam criando direta ou indiretamente um ciclo de amizade.

A aplicação do 5o Princípio do cooperativismo, onde diz que as cooperativas devem promover a educação e a formação dos seus membros, na cooperativa em estudo é um ponto favorável e levado a sério pela Direção. Notase nas pautas de reuniões e atas das assembleias a importância dada para esse princípio e a relevância do seu emprego para a integração social dos associados, além da educação e a formação dos seus membros, dos representantes eleitos e dos trabalhadores, de forma que estes possam contribuir, eficazmente, para o desenvolvimento da cooperativa.

Para a aplicação deste princípio existe um fundo especifico chamado FATES (Fundo de Assistência Técnica Educacional e Social), previsto no estatuto e na lei , que diz que a cooperativa é obrigada a separar das sobras, quando existir, no mínimo 5\% (cinco por cento), podendo alocar mais valores através de remanejamentos, mas sempre com acordo da assembleia. 
Através de coleta dos dados primários, nota-se o quão difícil é a mudança da percepção quando o assunto é Marketing voltado para a captação de novos associados. Essa estagnação de pensamento e atitude traz consequências para a cooperativa, pois não consegue vender o seus produtos, serviços e processos de forma eficaz. Percebe-se que na visão da diretoria é incumbência da comunidade descobrir as vantagens dessa forma de fazer negócio.

Mesmo sabendo da complexidade em demostrar para um determinado grupo o modelo de negócio cooperativista, não é a função dessa comunidade perceber as oportunidades que ela pode usufruir se tornando um associado. É atribuição da Cooperativa apresentar, de forma simples e clara, as possibilidades competitivas no ramo em que ela está inserida, a saber, crédito pessoal. As ferramentas de comunicação estão cada vez mais eficazes, com grande potencial de contribuição para a cooperativa e para captação de novos cooperados, podendo melhorar ainda mais o relacionamento e o atendimento ao associado.

Faltam informações pré-adesão cooperativista. Os serviços oferecidos pelas cooperativas de crédito são de longe muito mais baratos que os dos bancos. A taxa de juros cobrada para empréstimos também é bem menor. As Cooperativas emprestam a baixos juros comparativos com o mercado financeiro porque não tem o lucro como foco. As sobras positivas dos resultados são distribuídas aos associados. Embora a maioria das pessoas acredite que ter conta em banco ou cooperativa seja a mesma coisa, apenas com valores menores, esta máxima não é verdadeira. Ter conta em uma cooperativa de crédito significa ser sócio da mesma. $\mathrm{O}$ associado de uma cooperativa de crédito se beneficia de seu resultado positivo caso houver. Em contrapartida também será responsável por arcar com o prejuízo em caso de resultado negativo. É igualmente necessário demonstrar a existência de um estatuto, documento que deve registrar todas as normas de operação da cooperativa.

Segundo foi apurado o relacionamento entre a Cooperativa de Crédito $\mathrm{x}$ Instituição cadastrada, não são cordiais, a bastante tempo como deveria ser. Nota-se, invariavelmente, que a relação conflituosa entre Direção da Cooperativa e as Instituições de Ensino inscritas no cadastro de empregadores de cooperativados associados a esta Cooperativa, determina o não depósito em folha dos descontos desses associados relativos a empréstimos captados na 
Instituição Cooperativista. Essa relação política mal engendrada determina prejuízos à cooperativa e deve ser cuidada com mais atenção.

O problema ocorre no momento dos descontos originários de empréstimos junto à cooperativa, feito pelo cooperado, uma vez que a lei vigente impede o desconto de taxas e serviços superiores a $30 \%$ do valor salarial bruto recebido pelo trabalhador.

O obstáculo não termina somente nesse ponto delicado, segundo apurado a instituição também ignora o repasse dos funcionários/cooperados que por ventura venham a sair do emprego, ou seja, não é repassado para a cooperativa 0 valor referente a débitos de funcionários demitidos, quando o valor do capital $x$ valor de empréstimo é negativo. 


\section{Conclusões e Sugestões}

Considerado um movimento que só cresce em termos globais e que ganha cada vez mais força no Brasil, em especial onde as políticas públicas poucas vezes são capazes de alcançar a parcela menos favorável da população, o cooperativismo de crédito apresenta um crescimento expressivo e significativo para a economia brasileira, hoje o cooperativismo de crédito já é líder de mercado em algumas regiões do Brasil, contribuindo para o desenvolvimento da economia dessas localidades.

Apesar de ser um assunto relativamente novo a Governança Corporativa segue o mesmo ritmo do Cooperativismo, cada vez mais conquistando espaço nos mercados brasileiros, tornando-se um diferencial para as organizações empresariais e não empresariais, como as cooperativas e o Terceiro Setor.

No início de 2010 o BACEM, através da resolução n³859, publicou as diretrizes para a implementação das boas práticas de governança, uma cartilha incentivando a adoção das boas práticas de governança corporativa nas cooperativas de crédito, incentivando as cooperativas a aderirem a algumas dessas práticas, mas ainda é comum que as cooperativas enfrentem alguns desafios para adotar a estratégia.

Os objetivos propostos para este estudo foram respectivamente alcançados. O estudo revelou que a Coopcred-Ensino está quase em sua totalidade, alinhada com o documento publicado em 2009 pelo BACEM no qual aponta diretrizes e mecanismos para o fortalecimento das cooperativas de crédito, a maioria dos pontos abordados estão contidos no Estatuto Social da Cooperativa de Crédito em análise.

A divulgação e transparência de suas ações aos associados; o uso dos serviços de auditoria e do conselho fiscal independentes para examinar e assegurar com legitimidade as informações das contas contábeis; o estimulo à participação dos associados na cooperativa; os processos eleitorais; a 
aplicabilidade ao regimento interno; o respeito à soberania da Assembleia Geral ordinária ou extraordinária; a disponibilidade de código de Ética e de Conduta; a existência de uma ouvidoria com um canal de comunicação através de um telefone 0800 para seus associados, tudo isso reforça o compromisso da Coopcred-Ensino com a pratica de boa governança, de acordo com os princípios cooperativistas.

Apesar de apresentarem grau relevante, em aspectos positivos de diretrizes e mecanismo para o fortalecimento da governança em cooperativa de crédito, a Coopcred-Ensino deve buscar constante fortalecimento e aperfeiçoamento de evoluções e profissionalização que ajudem no desenvolvimento efetivo da sua gestão, reforçando os papéis da governança corporativa.

Um dos principais desafios da Coopcred-Ensino está relacionado à sua própria estrutura organizacional. $\mathrm{Na}$ implementação de um modelo de governança que passa a exigir a segregação de funções entre a diretoria executiva e a diretoria estratégica, que é uma das principais práticas recomendadas pelos organismos nacionais e internacionais. Com entendimento claro da função de cada um dos dirigentes, sejam estratégicos ou executivos, de modo, que não ocorram sobreposições de papéis, deixando de lado o método antigo de trabalho em sua gestão. Neste aspecto trata-se da própria cultura organizacional.

Conforme verificado nas atas das assembleias, as taxas de participação dos associados são pequenas se comparadas ao tamanho da cooperativa em estudo, nesse sentido sugere-se aos gestores da cooperativa encontrar medidas efetivas que envolvam mais os associados para que se sintam necessários dentro do processo de votação e de outros meios de participação.

Uma sugestão nesta época de pandemia, onde a situação de normalidade a seu fim estará longe do normal constatado em período a ele anterior, seria a adesão da cooperativa a plataformas de ensino e formação à distância (EAD), com a missão de viabilizar cursos de capacitação e formação à distância, levando aos cooperados novas formas de acesso ao conhecimento e de sociabilidade. 
Recomenda-se uma nova pesquisa para melhor captar do associado cooperativado seu nível de satisfação, assim como o grau de envolvimento dos associados que fazem parte do quadro social da cooperativa. Verificar o hábito dos cooperados em ler os informativos ou outro tipo de material de divulgação disponibilizados pela cooperativa em questão, para compreender os motivos reais da sua não participação no processo decisório da cooperativa e se por ventura fatores sociais tenham interferência nesse processo.

"Se formos analisar as relações desse associado, cooperado, entenderemos que seus anseios estão ligados ao atendimento imediato de demandas financeiras, empréstimos. Para isso esse indivíduo associa-se a uma Cooperativa de Crédito especificamente ligada à sua Categoria Profissional e contratualmente ligada à Instituição em que trabalha, possibilitando dessa forma o desconto de empréstimos e taxas associativas em contracheque". (Opinião de um cooperativista)

Em seu livro Responsabilidade Social e Governança (2006), Cláudio Pinheiro Machado Filho, corrobora com o pensamento expressado pelo o autor da frase, "O monitoramento do agente pelo principal é muito tênue, já que os direitos de propriedade sobre os resíduos tendem a ser dispersos, tendo em vista que todos os cooperados são sócios. A renda do cooperado decorre muito mais da venda de seu produto do que das eventuais "sobras" distribuídas ao final do exercício. Tal fato resulta em pouco incentivo para os principais (cooperados). 


\section{Referências Bibliográficas}

ARCARO, Mauricio Pietsch. Governança corporativa no cooperativismo de crédito: Uma abordagem em um modelo organizacional. Criciúma, 2014. 47 p. Universidade do Extremo Sul Catarinense - UNESC. Criciúma - SC.

BARBOSA, M. E. J. Gestão de Cooperativa: Um estudo relacional do modo de organização do trabalho e desempenho organizacional no ramo de transportes de pessoas. João Pessoa, 2010 Dissertação (Mestrado em Administração) - Centro de Ciências Sociais Aplicadas: Universidade Federal da Paraíba

BRASIL, C. B. Cooperativismo de Crédito: Boas práticas no Brasil e no Mundo. Brasília: Farol, 2016.

BRASIL, C. B. Governança Cooperativa - Diretrizes para boas práticas de Governança em Cooperativas de Crédito. Brasília: Banco Central do Brasil, 2008.

BÜTTENBENDER, L. P.; SCHREINER, M. D.; SPAREMBERGER, A.; BÜTTENBENDER, N. B. O processo de implantação de modelo de governança em uma cooperativa de crédito: um estudo de caso. RGC - Revista de Gestão e Organizações Cooperativas, Santa Maria, v. 8, n.15, 2021

CHIAVENATO, I. Introdução à teoria geral da administração: uma visão abrangente da moderna administração das organizações. Volume 7 , Rio de Janeiro: Elsevier, 2003

MACHADO FILHO, P. C Responsabilidade Social e Governança - o Debate e as implicações. São Paulo: Pioneira Thomson Learning, 2006

MELO, A. M.; BERTOLINI, G. R. F. Uma revisão teórica sobre os processos de gestão das cooperativas. RECoDAF - Revista Eletrônica Competências Digitais para Agricultura Familiar, Tupã, v. 3, n. 1

SANTOS, B. M.; SCHERER, L. F.; CAMPARA, P. J.; TRINDADE, R. N.; FERREIRA, V. M. G. Tipologias de governança corporativa em cooperativas de crédito no Brasil. RGC - Revista de Gestão e Organizações Cooperativas, Santa Maria, v. 8, n.16, 2021

SILVA, H. A.; CALEMAN, Q. M. S.; SILVA, H. J. A. Governança Cooperativa: As práticas de governança consideram os princípios cooperativistas? Uma análise acerca de manuais de boas práticas. RGC - Revista de Gestão e Organizações Cooperativas, Santa Maria, edição especial 01/2018

SOBRAL, F.; PECI, A. Administração - Teoria e prática no contexto brasileiro. n.2 São Paulo: Pearson, 2013

MELO, A. M.; BERTOLINI, G. R. F. Uma revisão teórica sobre os processos de 
gestão das cooperativas. RECoDAF - Revista Eletrônica Competências Digitais para Agricultura Familiar, Tupã, v. 3, n. 1

SILVA, H. A.; CALEMAN, Q. M. S.; SILVA, H. J. A. Governança Cooperativa: As práticas de governança consideram os princípios cooperativistas? Uma análise acerca de manuais de boas práticas. RGC - Revista de Gestão e Organizações Cooperativas, Santa Maria, edição especial 01/2018

SANTOS, B. M.; SCHERER, L. F.; CAMPARA, P. J.; TRINDADE, R. N.; FERREIRA, V. M. G. Tipologias de governança corporativa em cooperativas de crédito no Brasil. RGC - Revista de Gestão e Organizações Cooperativas, Santa Maria, v. 8, n.16, 2021

BÜTTENBENDER, L. P.; SCHREINER, M. D.; SPAREMBERGER, A.; BÜTTENBENDER, N. B. O processo de implantação de modelo de governança em uma cooperativa de crédito: um estudo de caso. RGC - Revista de Gestão e Organizações Cooperativas, Santa Maria, v. 8, n.15, 2021

SOBRAL, F.; PECI, A. Administração - Teoria e prática no contexto brasileiro. n.2 São Paulo: Pearson, 2013

MACHADO FILHO, P. C Responsabilidade Social e Governança - o Debate e as implicações. São Paulo: Pioneira Thomson Learning, 2006

CHIAVENATO, I. Introdução à teoria geral da administração: uma visão abrangente da moderna administração das organizações. Volume 7 , Rio de Janeiro: Elsevier, 2003

BRASIL, C. B. Governança Cooperativa - Diretrizes para boas práticas de Governança em Cooperativas de Crédito. Brasília: Banco Central do Brasil, 2008.

BRASIL, C. B. Cooperativismo de Crédito: Boas práticas no Brasil e no Mundo. Brasília: Farol, 2016.

GIL, A. C. Métodos e Técnicas de Pesquisa Social. São Paulo: Atlas, 2008

Vergara, C. S. Projetos e Relatórios de Pesquisa em Administração. São Paulo: Atlas, 1998

BARBOSA, M. E. J. Gestão de Cooperativa: Um estudo relacional do modo de organização do trabalho e desempenho organizacional no ramo de transportes de pessoas. João Pessoa, 2010 Dissertação (Mestrado em Administração) - Centro de Ciências Sociais Aplicadas: Universidade Federal da Paraíba

ARCARO, Mauricio Pietsch. Governança corporativa no cooperativismo de crédito: Uma abordagem em um modelo organizacional. Criciúma, 2014. 47 p. Universidade do Extremo Sul Catarinense - UNESC. Criciúma - SC.

Mundocoop. Revista de Informação e inspiração para o cooperativismo. Cooperativismo: um conceito que precisa ser mais divulgado - por Vera Caser https://www.mundocoop.com.br/artigos/cooperativismo-um-conceito-que-precisaser-mais-divulgado-por-vera-caser.html. Acesso em: 20 de outubro. 2021. 
https://www.sicoobcopermec.com.br/cooperativismo. Acesso em 10 de outubro. 2021

https://www.bcb.gov.br/pre/microFinancas/coopcar/pdf/DiretrizesVersaoCompleta .pdf. Acesso em 02 de novembro. 2021 